\title{
1 Performance of wheat-based cropping systems and economic risk of low relative productivity assessment in a sub-dry Mediterranean environment
}

\section{Abstract}

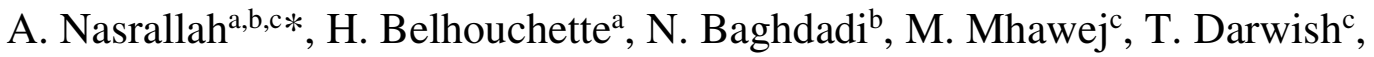 \\ S. Darwich ${ }^{\mathrm{d}}$, G. Faour ${ }^{\mathrm{c}}$ \\ ${ }^{a}$ CIHEAM-IAMM, UMR-System, 34090 Montpellier, France \\ ${ }^{b}$ IRSTEA, University of Montpellier, UMR TETIS, 34090 Montpellier, France \\ ${ }^{c}$ National Center for Remote Sensing, National Council for Scientific Research (CNRS), Riad al Soloh, Beirut 1107 2260, Lebanon \\ ${ }^{d}$ Faculty of Agriculture, Lebanese University, Beirut 99, Lebanon
}

The promotion of optimum rotations and agricultural management of winter wheat-based cropping systems is very critical, as wheat is considered an essential component in the Mediterranean diet. Considering the delicate economic situation of farmers in the Mediterranean area, recommending a low risk, sustainable farming system is desirable. In this study, an innovative application of a multi-criteria field-level approach is presented, targeting food security, farmer profitability and environmental sustainability. The CropSyst biophysical simulation model was calibrated and implemented for the study site. It was chosen for its agro-environmental robustness to simulate four rotations (wheatwheat, wheat-fallow, wheat-potato, and wheat-fava bean). Four types of wheat agricultural management systems (full fertilization and full irrigation, full fertilization and zero irrigation, zero fertilization and full irrigation, and zero fertilization and irrigation) were tested in low and high soil water holding capacity (WHC) types. The effects of soil conditions, management practices and rotation type on wheat grain yields were assessed. Furthermore, the performance of each winter wheat-based cropping system was evaluated in terms of productivity (protein production and profitability) and the efficient use of 
27 resources (nitrogen and water), as well as the economic risk of low relative productivity each one engenders. The results show that there is no particular optimal scenario that can simultaneously ensure high productivity, reduce economic risk of low relative productivity, and achieve high wheat- water- and nitrogen-use efficiency. However, the wheat-fava bean rotation cultivated with no wheat fertilization appeared to be a better substitute to the wheat-wheat rotation in terms of protein production $(0.93 \mathrm{t} / \mathrm{ha}$ versus $0.8 \mathrm{t} / \mathrm{ha}$ in low $\mathrm{WHC}$ soil and $1.34 \mathrm{t} / \mathrm{ha}$ versus $1.17 \mathrm{t} / \mathrm{ha}$ in high WHC). This cropping system achieved a higher net profit (2111 US\$/ha versus 1222US\$/ha in low WHC and 3550 US $\$ /$ ha versus 2450 US\$/ha in high WHC), showing high resource-use efficiency and was less risky for farmers. Moreover, a very high profit could only be attained with the wheat-potato rotation (8640 US\$/ha and 12170 US\$/ha in low and high WHC, respectively), yet with low inputefficiency and high economic risk of low relative productivity.

Keywords: Winter wheat, CropSyst, Risk, Efficiency, Management, Cropping system, Lebanon.

\section{Introduction}

Throughout history, the Mediterranean, especially its eastern and southern parts, has been known to be the origin of many landraces and a pioneer in food production. It has never been a region of abundance and glut, yet has always overcome the deficiencies in production (Braudel, 1990; Kehoe, 1988). Winter wheat (Triticum Durum L.) is one of the major crops grown in the Mediterranean. In Lebanon and the Middle East and North Africa (MENA) region, wheat is often financially and sometimes technically supported as a part of the governmental subsidy system. This self-sufficiency policy has long been the bedrock 
50 of food security, leading to the continuous cultivation and successive sowing of wheat (El 51 Khansa, 2017; Nasrallah et al., 2018). At the same time, the MENA region is the largest 52 cereal importer in the world, with over 58 million metric tons, covering more than $50 \%$ of 53 its consumption (Wright and Cafiero, 2010). For nations within the MENA region, 54 importing cereal grains (mainly wheat) is not a matter of choice, but a necessity (Ahmed 55 et al., 2014).

56 Even if policies and policy-makers are keen to encourage large cereal production (wheat 57 in particular), simple wheat-based cropping systems co-exist in the Mediterranean region 58 (MoA, 2010). Intensive local wheat production in monoculture (wheat-wheat rotations) has 59 always been coupled with drawbacks and nutrient mining and deficiency. According to 60 Sieling et al. (2005), wheat-following-wheat rotations indeed lead to reduced yields, 61 compared to wheat following a different crop. The main reasons behind this finding are (1) 62 the increase in biotic yield-limiting factors (Bennett et al., 2012) and (2) a lesser availability 63 of needed nutrients and particularly nitrogen (Dalal et al., 2001; Sieling et al., 2005). 64 Thereby, the different already existing wheat-based cropping systems (with different 65 rotation and management practices) are directly linked to soil water and nitrogen access 66 (Pala et al., 2007; Ryan et al., 2007), production type (e.g. cereal grains, legume grains or 67 vegetables), in addition to economic risk, which farmers can overcome (Komarek et al., 68 2015; Sadras, 2002).

69 Thus, several studies have tried to address the obvious question of the performance and 70 outputs of each production system. Diverse crop rotations have been experimented, and 71 sometimes versus monoculture systems (Beaudoin et al., 2005; Constantin et al., 2010;

72 Hansen et al., 2015, 2010; Macdonald et al., 2005; Moreau et al., 2012; Sieling and Kage, 
73 2006). For instance, long-term field experiments in Central and Western Europe have

74 shown that the inclusion of a catch crop within a rotation can indeed significantly increase

75 nitrogen-use efficiency (NUE) as well as the $\mathrm{N}$ (Nitrogen) uptake of the main crop

76 (Berntsen et al., 2006; Constantin et al., 2011). In comparing different types of wheat-based

77 rotations, Angus et al. (2015) found that both fallow-wheat and break crop-wheat rotations

78 generally produced greater yields than wheat-wheat rotations. For instance, legume-wheat

79 rotations generated over $20 \%$ wheat grain yields compared to wheat-wheat rotations.

80 Without underestimating the role of plant genetics, the efficient management of water and

$81 \mathrm{~N}$ has been identified as a crucial need for closing the yield gap, which is estimated by

82 comparing the observed yield with the attainable one (Mueller et al., 2012), of main cereal

83 crops (Sinclair and Rufty, 2012) notably on arid and semi-arid soils with low organic

84 carbon and nitrogen content (Darwish et al., 2018). Downscaling to field and farm levels

85 made it possible to study and analyse the economic risk that farmers and producers could

86 face, in relation to their adopted cropping systems (Di Falco and Perrings, 2005; Komarek

87 et al., 2015; Mahmood et al., 2017; Valle et al., 2004). However, the absence of a clear

88 integrated approach at field level, assessing different existing wheat-based cropping

89 systems regarding their productivity, resource-use efficiency and economic risk of low

90 productivity, represent the motivation of this study. It raises the key issue of the wheat-

91 based cropping systems to be promoted (regarding resources, soil types, climatic

92 variability, and management systems). It also offers a conceptual guide-map, allowing

93 policy-makers and producers to categorize different cropping systems with reference to

94 productivity (i.e. net profit and protein production), efficiency (water and nitrogen) and the 95 economic risk of low relative productivity. 
For this purpose, the biophysical simulation model "CropSyst" version 3 (Monzon et al.,

97 2012) was calibrated and evaluated in the mid-Bekaa plain in Lebanon based on extensive

98 field work. Scenarios concerning different existing wheat-based cropping systems (rotation

99 type and wheat management system) in two soil types with contrasting water holding

100 capacities were developed and run against historical long-period climatic data (i.e. 20

101 years). Based on the model outputs, the objectives of the paper were to first, to measure

102 and compare the effect of the different rotations (wheat-wheat, wheat-potato, wheat-fallow

103 and wheat-fava beans) and agricultural practices (water and nitrogen) on winter wheat

104 grain yield. Second, to evaluate and compare the performance of each cropping system (of 105 rotation type and agricultural practices) in terms of productivity and efficiency of utilizing 106 the resources. Finally, to establish the link between the performance of each cropping 107 system and its economic risk of low relative productivity.

\section{Methods}

\subsection{Study site and crop management}

110 The Bekaa plain in Lebanon is located between $33^{\circ} 33^{\prime} \mathrm{N}$ and $33^{\circ} 60^{\prime} \mathrm{N}$ latitude, $35^{\circ} 39^{\prime} \mathrm{E}$ 111 and $36^{\circ} 14^{\prime} \mathrm{E}$ longitude (Fig. 1). The area of the plain is around $860.25 \mathrm{~km}^{2}$ with an average 112 elevation of $1000 \mathrm{~m}$ above sea level. The dominant soils within the plain are mainly clay 113 to loam but differ in their water holding capacity (WHC). The Bekaa is characterized by a 114 semi-arid Mediterranean climate and the average annual precipitation is around $600 \mathrm{~mm}$. 115 In addition, agriculture is the main economic activity as field crops, orchards, annual and 116 perennial plants are cultivated. 
118 Field crop areas (e.g. cereals, vegetables, alfalfa and legumes) range from 0.1 ha to 20 ha.

$11965 \%$ of the national cereal production is produced in the Bekaa plain, while winter wheat 120 areas in the plain correspond to $44 \%$ of the national wheat area, occupying areas ranging

121 from 9000 to 12000 ha annually. 51\% of potato crops, which is one of the largest tuberous

122 crops cultivated in Lebanon, is cultivated in the Bekaa plain as one of the most important

123 cash crops. As for legumes, Bekaa is responsible for $20 \%$ of the national cultivation area,

$12416 \%$ of this area corresponds to fava beans, which occupy around 1548 ha in the plain

125 (MoA, 2010). Wheat and fava beans are winter crops, as they are sown in November, while

126 potatoes are sown in March.

127 Regarding irrigation management, $72 \%$ of Bekaa crops are fully or supplementary

128 irrigated. Even though fava beans and wheat are grown during the winter season, they

129 receive supplementary irrigation during early spring to ensure better yields, although $20 \%$

130 of the wheat in the Bekaa plain is not supplementary irrigated (due to no access to water,

131 money shortage and/or in the hope of a good rainy season) (El Khansa, 2017). While

132 potatoes, on the other hand, are fully irrigated (on a weekly basis) from sowing to

133 harvesting, ranging from 10 to $20 \mathrm{~mm}$ per application, depending on the phenological stage

134 (Darwish et al., 2003, 2006a).

135 Fertilization is supplied, especially nitrogen, being one of the most growth driving nutrient.

136 Fertilization management practices differ among farmers, however, nitrogen is supplied in

137 both organic and inorganic forms. In the case of wheat, farmers supply nitrogen in amounts

138 of up to $230 \mathrm{~kg} \mathrm{ha}^{-1}$ as ammonium sulfate at emergence and before the flowering stages.

139 However, up to $15 \%$ of wheat farmers do not apply synthetic fertilization. This is mainly 
due to the cultivation of potato as a previous crop, where the land is supposed to be fertile enough to meet wheat nitrogen demands, besides other economic considerations and

142 money saving purposes, when necessary. As for potato crops, nitrogen is applied before

143 planting in the form of manure (around $250 \mathrm{kgN} \mathrm{ha}^{-1}$ ), in addition to a second application

144 of nitrogen (around $100 \mathrm{kgN} \mathrm{ha}^{-1}$ ) before the inception of flowering. When fertilized, fava

145 beans receive a triggering amount of $50 \mathrm{kgN} \mathrm{ha}^{-1}$ of nitrogen 60 days after sowing.

146 In the Bekaa plain, one of the most followed rotation types is the wheat-potato rotation as

147 it is one of the most profitable rotations. In fact, the existence of wheat-legume rotations is 148 limited within the Bekaa plain. However, some farmers do cultivate wheat in monoculture 149 to benefit from governmental support in buying their harvest with relatively good prices. $15023 \%$ of wheat cultivated land in 2016 had also been wheat cultivated in 2017 (Nasrallah et 151 al., 2018). Therefore, among suitable agriculture land, less than 1500 ha of land are left as 152 fallow annually, corresponding to $4 \%$ of the total exploited area.

\subsection{Simulation model}

\subsubsection{CropSyst model description}

156 The CropSyst model, which was first presented by Stockle et al. (2003, 1994), uses

157 weather, soil and crop input data for the estimation of crop productivity under different 158 management conditions (water and nutrient input). It has been widely applied to many 159 regions (e.g. USA, China, Central and Northern Europe and the Mediterranean) and crops 160 (e.g. cereals, vegetables and legumes) (Ahmad et al., 2017; Belhouchette et al., 2008; 161 Brooks et al., 2017; Palosuo et al., 2011; Rötter et al., 2012), especially for its ability to 
work on a daily basis for simulating multi-crop scenarios, in addition to water-soil dynamics (Richard's equation for our case) and nitrogen budgets.

\subsubsection{Datasets for model calibration and evaluation}

\section{Experimental datasets for winter wheat model calibration and evaluation}

166 Five winter wheat plots were selected within the region of mid-Bekaa, corresponding to 167 two dominant soil types with different water holding capacities (low: $100-175 \mathrm{~mm} / \mathrm{m}$ and high: $175-250 \mathrm{~mm} / \mathrm{m}$ ). Above ground biomass (AGB), dry matter production (DMP), soil water content (SWC), and above ground nitrogen (AGN) were measured at four physiological stages and replicated three times within each winter wheat plot (Table 1).

173 Above ground biomass (AGB) was measured by a destructive method. After weighing the

174 fresh samples for each replication within each plot, the samples were cut up, mixed and 175 quartered and a representative sample was oven dried at $70{ }^{\circ} \mathrm{C}$ until constant weight was 176 reached (Catchpole and Wheeler, 1992).

177 Soil water content (SWC) was measured using the gravimetric method. For each of the 178 three pedological horizons (the depth of each soil horizon varied among plots), a sample 179 of soil was taken out, weight measured fresh, then sent to the oven to dry at $105{ }^{\circ} \mathrm{C}$ until constant weight was obtained. For each winter wheat reference plot, the measurement was replicated three times randomly at each depth at five crop development stages (Reynolds, 182 1970). 
Above ground nitrogen (AGN) was measured following the Kjeldahl N method (Rodriguez and Miller, 2000). Crop $\mathrm{N}$ uptake for each treatment was calculated based on the corresponding data of dry matter production and $\mathrm{N}$ content for each treatment, at each sampling date. Winter wheat in-situ measurements are summarized in table 2 . It shows the minimum, maximum and average results of the measurements of replications. SWC measurements in the different horizons were also considered.

\section{Survey datasets for potato and fava bean model calibration and evaluation}

A survey was conducted in the study site inquiring about potato and fava bean crops (four farmers of each crop type), including sowing and harvesting dates, management practices and yields. Table 3 includes the characteristics of potato and fava bean plots, to which data on sowing and harvesting dates, management practices and yields correspond.

Weather data (daily data on precipitation, maximum air temperature, minimum air temperature and incoming solar radiation from 1997 to 2017) were collected from a station located in the study area (Zahle).

\subsubsection{Model calibration and evaluation process}

Following Belhouchette et al. (2008), only the two most sensitive parameters were calibrated for simulation with CropSyst, namely: the above ground biomass transpiration coefficient $\left(A G B_{T}\right)$ and the conversion of light to above ground biomass coefficient 
$206\left(A G B_{I P A R}\right)$. These parameters were derived manually by changing the crop parameters until

207 a satisfactory agreement between the predicted and simulated yield and biomass was 208 achieved (Singh et al., 2008). While for potato and fava bean crops, the calibration was 209 based on yields reported through the questionnaire conducted, as suggested by Komarek et 210 al. (2017).

211 CropSyst was validated by comparing the simulated and measured values of the observed 212 plots used for validation (section 2.2.2, Tables 1, 2 and 3), which were not part of the 213 calibration process (one plot of each crop was used for calibration, while the others were 214 used for validation). In the case of wheat, these values correspond to AGB, AGN, and SWC 215 over the whole growing cycle, while for potato and fava bean crops, according Komarek 216 et al. (2017), only the yield was validated after calibration. Root Mean Square Error 217 (RMSE) was used to calculate the error of estimates as:

$218 \quad R M S E=\left[N p^{-1} \sum_{i=1}^{N}\left(P_{i}-O_{i}\right)^{2}\right]^{0.5}$

219 where $N p$ is the number of pairs of observed $\left(\mathrm{O}_{\mathrm{i}}\right)$ and simulated $\left(\mathrm{P}_{\mathrm{i}}\right)$ data.

220 Then, the RMSE was computed relative to the mean of the observed values $(\overline{\mathrm{O}})$ as:

$221 \quad R R M S E=\frac{R M S E}{\overline{0}}$

222 To have proper insight on the model efficiency, the model efficiency "EF" indicator was 223 calculated as:

$224 E F=1-\frac{\sum_{i=1}^{N}\left(P_{i}-O_{i}\right)^{2}}{\sum_{i=1}^{N}\left(O_{i}-\bar{O}\right)^{2}}$ 
225 The model efficiency indicator varies from $-\infty$ to +1 . Negative values can indicate bias in

226 linear models, yet could not be the case in non-linear models.

227 As an indicator to estimate correlation/regression, index of agreement "d" was calculated 228 as:

$229 d=1-\frac{\sum_{i=1}^{N}\left(P_{i}-O_{i}\right)^{2}}{\sum_{i=1}^{N}\left(\left|P_{i}-\bar{O}\right|+\left|O_{i}-\bar{O}\right|\right)^{2}}$

where $\mathrm{O}_{\mathrm{i}}$ represents the observed data, $\mathrm{P}_{\mathrm{i}}$ represents the predicted data and $\overline{\mathrm{O}}$ is the average

231 of the observed data. The Willmott index of agreement (d) varies from 0.0 (poor model) to

2321.0 (perfect model), similar to the interpretation of the coefficient of determination (R2).

233 Eqs. 3, 4, 5 and 6 were applied to the validation plots within the region (four winter wheat

234 plots, three potato plots, and three fava bean plots), to make sure that by changing the 235 management practices and initial conditions, the model kept on generating satisfactory 236 estimates.

\subsection{Developing the scenarios to be simulated by the CropSyst model}

239 In this study, different wheat-based cropping systems of different rotation types (wheat240 wheat, wheat-fallow, wheat-potato, and wheat-fava bean, see Table 3) in two soil water 241 holding capacity (WHC) types, are simulated. The two soil types consist of different 242 horizons of different depth. Table 4 illustrates the soil characteristics of each soil type. 243 Each soil type is not uniform in terms of depth, rather consists of separate soil horizons. 
246 We note hereby that full fertilization (Nitrogen) and full irrigation (water) follow the

247 amounts applied on the plot used for calibration (Plot ID 1 in Table 1), using the fixed

248 fertilization and fixed irrigation at fixed dates in CropSyst model. Four types of wheat

249 management systems were considered:

250 F1-I1: Full fertilization $\left(230 \mathrm{kgN} \mathrm{ha}^{-1}\right)$ and full irrigation $(100 \mathrm{~mm})$

251 F1-I0: Full fertilization $\left(230 \mathrm{kgN} \mathrm{ha}^{-1}\right)$ and no irrigation.

252 F0-I1: No fertilization and full irrigation $(100 \mathrm{~mm})$.

253 F0-I0: No fertilization and no irrigation.

254 Thus, it is noted that during the simulations, these different management practices are only 255 applied in the case of wheat, while the management of potato and fava bean crops does not 256 change (management of Potato 1 and Fava bean 1 in Table 3 are used for simulation). As 257 shown by El Khansa (2017), potato farmers do not alter their water and fertilizer inputs as 258 they know in advance the high risk this involves. In the case of fava beans, the management 259 is fixed, a small amount of nitrogen is the only input they apply, if any.

260 Each cropping system scenario is run from 1997 to 2017. The output of each scenario 261 (cropping system) is 20 simulated years composed of 10 rotations (each lasts 2 years).

262 Table 5 summarizes the scenarios simulated. We note that the irrigation was simulated in 263 CropSyst using a fixed amount of water in a fixed time, as expressed by the farmers during 264 our survey. 

performance of wheat-based cropping systems

270 - The net profit (US\$ ha-1) indicator: computed at rotational level (2 years) as follows:

$271 N P_{r}=\operatorname{Rev}_{r}-$ Cost $_{r}$

272 Where $N P$ stands for net profit at rotational level $(r)$, Rev stands for revenue per rotation

$273(r)$ and Cost stands for the variable production cost of each rotation $(r)$. We note hereby

274 that the variable production cost (Cost) represents all the costs needed to establish a

275 particular rotation. As the total simulation period is 20 years, the net profit is calculated 10

276 times for each cropping system.

277 In order to calculate the $\operatorname{Rev}_{r}$ and the $\operatorname{Cost}_{r}$ (Eq. 7) of each of the cropping systems, data on

278 input costs and output prices were collected through a local survey conducted at the study

279 site (Table 6), since in Lebanon, there is a lack of national official statistical sources for

280 annual input and output costs and prices. The input costs collected correspond to costs

281 related to cultivation (wheat, potato or fava bean), while output prices refer to selling the

282 produce (i.e. wheat grain yield, straw yield, potatoes, and fava bean grains). The input costs

283 and output prices collected through our survey correspond to an average of 5 years as the

284 prices are more or less stable and do not witness dramatic fluctuations. This also appears

285 when comparing to FAOSTAT (http://www.fao.org/faostat/) data. Regarding the

286 respondents, costs related to wheat were asked from 10 wheat farmers, costs related to

287 potato were asked from 10 potato farmers and costs related to fava bean were asked from

2886 fava bean farmers. The farmers were selected randomly, yet we intended to interview 
289 those who have been exercising the cultivation for a relatively long period (minimum 10 290 years). In addition, we aimed asking farmers who own their lands. The responses collected

291 from these farmers (Table 6) were homogeneous by looking at the averages and the 292 standard deviations.

293 It is noted that the input costs for both potato and fava bean crops are the variable 294 production costs including costs of fertilizer, water seeds, and labour. As simulating 295 different management systems is only carried out in the case of wheat, the variable 296 production cost (the only cost considered) to establish potato or fava bean cultivation is 297 equal to the input cost (Table 6) and does not change with the different scenarios.

300 - The average protein production $\left(\mathrm{kg} \mathrm{ha}^{-1}\right)$ indicator is computed at rotational level 301 following two equations (Eqs. 8 \& 9) for each cropping system. The purpose of this is to 302 serve comparing rotations of different crops within, to eventually come up with conclusions 303 on the protein production of each rotation.

304 First, the protein production $\left(\mathrm{kg} \mathrm{ha}^{-1}\right)$ for each rotation is computed by considering the final 305 yield of each crop within the rotation and its corresponding protein percentage:

$306 P_{r}=\left[\right.$ Yield $\left._{\text {Crop } 1} \times \% P_{\text {Crop } 1}\right]+\left[\right.$ Yield $\left._{\text {Crop } 2} \times \% P_{\text {Crop } 2}\right]$

307 where $P_{r}$ is the amount of protein $\left(\mathrm{kg} \mathrm{ha}^{-1}\right)$ produced by each rotation (r) (2years), Yield Cropl $_{1}$ 308 is the yield $\left(\mathrm{kg} \mathrm{ha}^{-1}\right)$ of the first crop within the rotation, Yield Crop $2_{2}$ is the yield $\left(\mathrm{kg} \mathrm{ha}^{-1}\right)$ of 309 the second crop within the rotation, $\% P_{\text {Cropl }}$ is the percentage of protein contained in $1 \mathrm{~kg}$ 
310 of the yield of crop 1 and $\% P_{\text {Crop } 2}$ is the percentage of protein contained in $1 \mathrm{~kg}$ of the yield

311 of crop2. Equation 8 is applied 10 times for each cropping system.

312 Yield $_{\text {Crop } 1}$ and Yield Crop $2_{2}$ are obtained from the CropSyst outputs. As for $\% P_{\text {Crop } 1}$ and

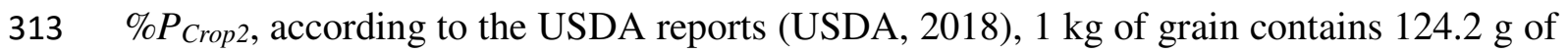

314 protein, $1 \mathrm{~kg}$ of potato tuber- contains $25.7 \mathrm{~g}$ of protein and $1 \mathrm{~kg}$ of fava bean- contains

$315261.2 \mathrm{~g}$ of protein.

316 Then, the accumulated protein amounts of the 10 rotations $(\mathrm{Nr})$ within each cropping

317 system are added up. Eventually, the average is measured by dividing the product by the

318 total number of rotations within each cropping system:

$319 \quad \bar{P}_{r}=\frac{\sum_{r=1}^{N r}\left(P_{r}\right)}{N r}$

320 where $\bar{P}_{r}$ is the average protein production $\left(\mathrm{kg} \mathrm{ha}^{-1}\right)$ at rotational level. $r$ is the rotation. $\mathrm{Nr}$

321 is the total number of rotations (=10 in this study).

322 Calculation of the efficiency indicators

323 The nitrogen-use efficiency (NUE) (Darwish et al., 2006a; Gaudin et al., 2015;

324 Rahimizadeh et al., 2010) and water-use efficiency (WUE) (Kang et al., 2002; Sadras,

325 2004) for the average 10-year wheat crop presented in each of the cropping systems

326 (rotation type and wheat management) are computed following two equations (Eqs. 10 \&

$32711)$

$328 \quad N U E_{\text {Wheat }}=\frac{A G N_{1}}{\left(N_{\text {Supply } 1}+T S M\right)}$

$329 W U E_{\text {Wheat }}=\frac{G Y}{E T_{\text {Actual }}}$ 
where $N U E_{\text {Wheat }}$ is the nitrogen-use efficiency calculated for the 10-years (out of a total of

33120 years $)$ of the wheat crop. $A G N_{I}\left(\mathrm{kgN} \mathrm{ha}^{-1}\right)$ stands for above ground nitrogen when wheat

332 is fertilized. $N_{\text {Supplyl }}$ corresponds to the amount of supplied $\mathrm{N}$ fertilizer $\left(\mathrm{kgN} \mathrm{ha}^{-1}\right)$, when

333 applied. TSM corresponds to total soil mineralization rate accounting for $\mathrm{N}$ soil pool $(\mathrm{kgN}$

$334 \mathrm{ha}^{-1}$ ). WUE Wheat is the water-use efficiency calculated for the 10years (out of a total of 20

335 years) of wheat cultivation. $G Y$ corresponds to grain yield. $E T_{\text {Actual }}$ stands for

336 evapotranspiration (mm).

337 Then, the apparent recovery efficiency by difference (ARED) is compared following 338 equations $12 \& 13$, to capture the added value of supplied $\mathrm{N}$ fertilizers and irrigation to 339 wheat within the different cropping systems.

$340 A R E D_{N}=\frac{A G N_{1}-A G N_{0}}{N_{\text {Supply } 1}-N_{\text {Supply }}}$

$341 \quad A R E D_{W}=\frac{G Y_{1}-G Y_{0}}{W_{\text {Supply } 1}-W_{\text {Supply }}}$

342 where $A R E D_{N}$ and $A R E D_{W}$ correspond to apparent recovery efficiency by difference, for 343 nitrogen and water respectively. $N_{\text {Supplyo }}$ corresponds to the amount of supplied $\mathrm{N}$ fertilizer $344\left(\mathrm{kgN} \mathrm{ha}^{-1}\right)$, when not supplied, which is equal to zero. $A G N_{0}\left(\mathrm{kgN} \mathrm{ha}^{-1}\right)$ corresponds to the 345 above ground $\mathrm{N}$ when wheat is never fertilized. $G Y_{l}\left(\mathrm{~kg} \mathrm{ha}^{-1}\right)$ and $G Y_{0}\left(\mathrm{~kg} \mathrm{ha}^{-1}\right)$ stand for 346 grain yield under full irrigation and no irrigation at all, respectively. $W_{\text {Supplyl }}$ stands for the 347 amount of water supplied as irrigation (mm). $W_{\text {Supplyo }}$ is the amount of water supplied as 348 irrigation (mm), when not supplied, which is equal to zero. 
350 Taking into account that in the area (MENA region and many developing countries), access

351 to banks' credits or other credit institutions has hardly been established or has fallen in

352 disorder (Asseldonk et al., 2013), the risk calculation considered in this study is in line with

353 the farmers' concerns of being financially secured to keep on sustaining their cropping

354 system with no or low financial failure by mobilizing their net profit to invest in the rotation

355 that follows by covering its variable production cost. The financial failure considered here

356 is not being able to re-establish their rotations for preserving their livelihoods. In practice,

357 this is seen when the net profit of a particular rotation in year 1 is less than the variable cost

358 of the same rotation in year 2, meaning that the farmer who wishes to re-cultivate this

359 particular system, must mobilize external resources to increase the difference between the 360 net profit and the variable production cost. The risk calculation proposed is an original 361 procedure different from the standard calculations within the literature. The variation in the 362 risk in this study is basically related to yield variations as prices in the area are seen more 363 or less stable over the last years. In addition, it is important to mention that the risk 364 considered in this study is to compare different cropping systems (scenarios). In other 365 words, when the financial failure is seen, it does not mean that the farmer's livelihood is 366 terminated, yet they witness a risk of not being able independently in re-cultivating the 367 same system for the next rotation (two coming years), by covering its total production 368 costs.

369 Concretely, the economic risk of low relative productivity, which is expressed as a score, 370 is calculated as follows:

$371 \operatorname{Risk}_{C S}=\left(\sum_{r=1}^{N r} W_{r} \times\left(+R D_{r}\right)\right) \times F_{r / N r}$ 
372 where Risk $k_{c s}$ is the economic risk score that will be assigned to each of the cropping 373 systems, taking into account the 10 rotations within. $r$ corresponds to the rotation. $\mathrm{Nr}$ 374 corresponds to the total number of rotations $(\mathrm{Nr}=10)$.

$375 W_{r}$ is the normalized weight of the variable production cost at rotational level. As the tested 376 rotations have different production costs (different crops and management systems), a 377 normalized weight of the variable production cost is computed for each rotation, as a ratio 378 of the production costs of different rotations to the production cost of the most expensive 379 rotation (i.e. wheat-potato). Weight is calculated as follows:

$380 \quad W_{r}=\frac{\text { Cost }_{r}}{\operatorname{cost}_{W P}}$

381 where $W_{r}$ is the weight of each rotation varying between 0 and 1, Cost $_{r}$ is the full production 382 cost of a rotation, $\operatorname{Cost}_{W P}$ corresponds to the full production cost of the wheat-potato 383 rotation type.

$384 R D_{r}$ is the relative deviation of the net profit from the cost at each rotation. Given that the 385 farmer will continue applying the same rotation type and wheat management system, the 386 relative deviation of this net profit/rotation from the total cost needed to re-establish the 387 same rotation (of the same rotation type and wheat management system) is computed as 388 follows:

$389 R D_{r}=\frac{\text { Cost }_{r}-N P_{r}}{\text { Cost }_{r}}$ where $R D_{r}$ is the relative deviation of the net profit from the cost for each rotation within each cropping system, Cost $_{r}$ is the variable production cost of a particular rotation (e.g. wheat-wheat in F1-I1 management system) and $N P_{r}$ is the net profit of this particular 
rotation within a particular cropping system. It is noted that within the whole period (20

394 years) of simulation in a particular cropping system (10 rotations), the Cost $_{r}$ is fixed and 395 doesn't change, while the $N P_{r}$ changes for every rotation (2 years). If the output of $R D_{r}$ is 396 negative, meaning that the $N P_{r}$ is higher than the Cost $_{r}$, then the corresponding rotation is 397 neglected and is not considered when applying Eq. 14.

$398 \quad F_{r / N r}$ is the frequency of rotations (ratio from 0 to 1 ) whose net profit is lower than the 399 variable production cost, out of the 10 rotations $(\mathrm{Nr})$. To highlight the repetition of rotations 400 with a deficit (positive $R D_{r}$ ), i.e. in which the net profit is lower than the cost, the ratio of 401 the occurrence of this "bad" event from the whole number of rotations $(\mathrm{Nr}=10)$ is computed 402 as follows:

$403 \quad F_{r / N r}=\frac{\# \text { Positive } R D_{r}}{N r}$

404 where \#Positive $R D_{r}$ is the number of rotations within a cropping system whose $R D_{r}$ is 405 positive $\left(N P_{r}<C_{o s t}\right)$. Eq. 17 is applied for each of the 16 cropping systems, in both low 406 and high WHC soils.

\section{3. Results}

\subsection{Calibration and validation of the CropSyst model}

410 The results of the validation of the CropSyst model are therefore generated after the 411 calibration. Following the rating proposed by Jamieson et al. (1991), the RRMSE ranged 412 between $9.2 \%$ and $12.7 \%$, it can thus be considered as good to excellent simulation of dry 413 matter production (DMP). For above ground nitrogen (AGN) simulation, RRMSE ranged 
414 from $7.7 \%$ to $25.0 \%$ and can be considered as average to good. In the case of the average 415 soil water content (SWC) simulation, RRMSE ranged from $21.0 \%$ to $34.3 \%$. As regarding 416 the efficiency indicator (EF), for the DMP, the values ranged between 0.946 and 0.99 , 417 between 0.9 and 0.99 for AGN and between -5.5 and -0.57 for SWC. Concerning the index 418 of agreement (the correlation/regression indicator), the values ranged between 0.990 and 4190.996 for the DMP, between 0.96 and 0.997. As for the SWC, the index of agreement 420 produced values between 0.53 and 0.64 . Hence, the calibrated model can be counted as 421 satisfactory in terms of simulating yield, water, and nitrogen cycles.

3.2. Wheat grain yield as altered by the effects of rotation, management system, and soil type

424 The effects of different management systems, soil WHC, and rotations on wheat grain 425 yields $\left(\mathrm{kg} \mathrm{ha}^{-1}\right)$ are compared for the different wheat-based systems, as shown in Table 7. 426 Before applying the mean separation test, we checked for homogeneity (using Chi-square 427 test) and normality (using Shapiro Wilk's W test) assumptions. For all our cases, the null 428 hypothesis was rejected by the Chi-square test confirming that the rotation types are linked 429 to the wheat grain yield (significant results) and non-significant for the Shapiro-Wilk's W 430 test, thus the normality assumption was checked. Tuckey test (2-way ANOVA analysis) 431 was used to its ability in reducing type 1 and 3 errors (Acutis et al., 2012)

434 In low WHC soil, wheat grain yields produced by a wheat-potato rotation were the highest 435 (with no clear effect of the rotation type). However, in all rotations, wheat grain yields 
436 significantly decrease as the input amounts (fertilization and irrigation) decrease or are not 437 applied (e.g. in the case of a wheat-potato rotation it drops from $4515 \mathrm{~kg} \mathrm{ha}^{-1}$ in F1-I1 to $438 \quad 3433 \mathrm{~kg} \mathrm{ha}^{-1}$ in F0-I0.

439 When wheat is fertilized with no irrigation (F1-I0), wheat grain yields in a wheat-wheat 440 rotation $\left(3787 \mathrm{~kg} \mathrm{ha}^{-1}\right)$ are similar to those observed in a wheat-potato rotation $(3757 \mathrm{~kg}$ $441 \mathrm{ha}^{-1}$ ), meaning that water stress in such a soil type (low WHC) is more significant than 442 nitrogen stress. This finding agrees with the results reported earlier (Huang et al., 2003). 443 When wheat is not fertilized (irrigated or not), wheat grain yields in wheat-fallow and 444 wheat-fava bean rotations are higher than those observed in a wheat-wheat rotation (e.g. $4453873 \mathrm{~kg} \mathrm{ha}^{-1}$ in a wheat-fava bean rotation versus $3447 \mathrm{~kg} \mathrm{ha}^{-1}$ in a wheat-wheat rotation) 446 and similar to those observed in a wheat-potato rotation $\left(3280 \mathrm{~kg} \mathrm{ha}^{-1}\right.$ in a wheat-fava bean 447 rotation versus $3433 \mathrm{~kg} \mathrm{ha}^{-1}$ in a wheat-potato rotation). This means, indeed, that fallow 448 and fava bean when in rotation with wheat better mitigate water and nitrogen stresses on 449 wheat grain yields, in comparison with wheat-wheat rotation. This result is in agreement 450 with other findings (López-Bellido et al., 2012).

451 In high WHC soil, when wheat is fertilized (F1-I1 and F1-I0), there is no significant effect 452 of the rotation type on the wheat grain yield production. This is primarily attributed to the 453 type of soil (high WHC) that can hold more green water than low WHC. Hence, the loss in 454 yield that appeared in all the rotations from irrigated to rain-fed in high WHC (I1 to I0) is 455 due to water stress. Similar results were reported in the region (Sohi et al., 2009). However, 456 this loss is not as prominent as the one seen in low WHC soil (11\% versus $18 \%$ of wheat 457 grain yield drop). 

However, when nitrogen is limited (F0-I1 and F0-I0), as was reported for the soils of the NENA region (Darwish et al., 2018), the wheat-wheat rotation always leads to significantly lower wheat grain yields $\left(4665 \mathrm{~kg} \mathrm{ha}^{-1}\right.$ ) than the other tested rotation types (over $5200 \mathrm{~kg}$ $\left.\mathrm{ha}^{-1}\right)$. This is because wheat-fallow and wheat-fava bean rotations are less intensive in terms of nitrogen demand, and do not neglect the nitrogen fixation ability of legumes (Constantin et al., 2010; Moreau et al., 2012), as well as the fertilization of potatoes in the wheat-potato rotation. This means that nitrogen and water stresses are higher in the case of a wheat-wheat rotation when compared with other rotations.

Nevertheless, still in high WHC soils, wheat-wheat is the only rotation in which wheat grain yields did drop significantly when changing from a wheat intensive management system (F1-I1) (6083 $\left.\mathrm{kg} \mathrm{ha}^{-1}\right)$ to wheat semi-intensive management systems (F1-I0 and F0I1) (5250 $\mathrm{kg} \mathrm{ha}^{-1}$ and $5126 \mathrm{~kg} \mathrm{ha}^{-1}$, respectively), as well as when both nitrogen and water were ceased (F0-I0) (4665 $\left.\mathrm{kg} \mathrm{ha}^{-1}\right)$. This suggests that avoiding wheat intensive management systems (when in rotation with fallow, potato and fava bean) would not cause water nor nitrogen stress, preserving the level of wheat grain yields.

\subsection{Nitrogen and water Apparent Recovery Efficiency by Difference (ARED)}

474 To grasp the added value of input resources (water and nitrogen) on wheat grain yields, the 475 Apparent Recovery Efficiency by Difference (ARED) for the two input resources (Keller 476 and Keller, 1995; Rao et al., 1992) is calculated, for wheat grain yields following different 477 previous crops (wheat, fallow, potato and fava bean) in the two soil water holding 478 capacities (low and high) [Eqs. (12) \& (13) section 2.4.1]. ARED was computed for 479 nitrogen in both cases of irrigation (I1 and I0), as well as for irrigation in both cases of 
480 nitrogen supply (F1 and F0) (Fig. 2). The separation of means was done using 2-way 481 ANOVA analysis (Tukey test).

482 Concerning fertilization, wheat grain yields increased the most because of nitrogen 483 fertilization $\left(\mathrm{ARED}_{\mathrm{N}}\right)$ when cultivated in a wheat-wheat rotation, whether irrigated or not, 484 in low WHC soil (Fig. 2i \& 2iii) (4.61 and 2.79, respectively) or in high WHC (Fig. 2ii \& $4852 \mathrm{iv}$ ) (4.3 and 2.46, respectively). This means that for each $1 \mathrm{~kg}$ of added $\mathrm{N}$, the increase in 486 grain yields for wheat in the wheat-wheat rotation is greater than that observed in other 487 rotations. In other words, wheat grain yields in a wheat-wheat rotation will be more 488 sensitive to lower fertilization, and thus more likely to decrease than wheat grain yields in 489 other rotations. The lowest slope observed for wheat grain yields was in the case of a wheat490 fava bean rotation, conforming to several studies that show that fava bean is an excellent 491 previous crop (Angus et al., 2015; Plaza-Bonilla et al., 2017; Yau et al., 2003), which partly 492 reduces the dependence of the main crop (winter wheat in this case) on nitrogen fertilization 493 (Voisin et al., 2013).

494 In the case of wheat-fallow and wheat-potato rotations, the results were more nuanced. In 495 low WHC soil, fallow land allows for a better use of $\mathrm{N}$ than potato as a previous crop, as 496 soil nutrients are rebalanced and soil biota is re-established (Plaza-Bonilla et al., 2017). On 497 the other hand, potato becomes a better previous crop than fallow land in high WHC soils. 498 This is due to the ability of these soils to store more water and facilitate the flux of nitrogen 499 to the roots by mass flow, for the next crop.

500 Concerning irrigation, the results are quite surprising as in low WHC (Fig. 2v), wheat in a 501 wheat-wheat rotation requires less water (in terms of irrigation) than in other rotations, 502 which contradicts other studies that show that wheat is more sensitive to irrigation (thus 
more dependent) in a wheat-wheat rotation type (Gu et al., 2002; Musick et al., 1994;

504 Zhang and Oweis, 1999). This result can be explained by larger periods of fallow land than in the case of wheat-wheat rotations (maximum of 3 months of fallow). Therefore leading to larger amounts of evaporated water. This evaporated water, however, becomes less

507 important in high WHC (Fig. 2vi), in which more water is stored to its high capacity. In 508 coherence with the literature (Passioura and Angus, 2010), well-fertilized wheat (F1) 509 becomes more water reactive in a wheat-wheat rotation than other rotations. On the other 510 hand, wheat in a wheat-fava bean rotation becomes more reactive to water if nitrogen is 511 not applied. These results are consistent with multiple published studies, which state that 512 legumes are excellent previous crops, especially in a poorly fertilized system.

3.4. Trends of the crops' yields ( 10 rotations) over the simulation period

514 Out of the period of 20-years of simulation, 10 particular years $(1998,2000,2002,2004$, $5152006,2008,2010,2012,2014$ and 2016) witnessed the cultivation of each of the three 516 crops (wheat, potato and fava beans). In Figure 3 below, the trends of each of the three 517 crops is represented, for both water holding capacity soils (WHC). In each year, four 518 agricultural practices were simulated (Table 5). Thus, as we aim to show the general trend, 519 the values of the four outputs of the four agricultural practices simulated were averaged.

520 The average wheat grain yield trend shows a slight increase until the $6^{\text {th }}$ rotation $(1998$ till 521 2008), then a sharp drop until the $8^{\text {th }}$ rotation (2012) then an increase afterwards. Similar 522 to the trend of winter wheat, the yield of fava beans increased from the $1^{\text {st }}$ rotation till the $5232^{\text {nd }}$ one, then slight increase till the $6^{\text {th }}$ rotation before the sharp drop till the $8^{\text {th }}$ rotation 524 (2012). An increase was seen afterwards till the $9^{\text {th }}$ rotation before finally a decrease at the $52510^{\text {th }}$ one. As for potato, the trend was more or less stable with a slight decrease until the $7^{\text {th }}$ 
526 rotation, continues decrease was seen till the $8^{\text {th }}$ rotation before a sharp increase at the $9^{\text {th }}$ 527 and $10^{\text {th }}$ rotation.

545 fertilized, which is relatively consistent with previous studies (Asseng et al., 2001; Ben

546 Zekri et al., 2018; Garabet et al., 1998). Residual soil nitrogen can be subject to nitrification

547 in well aerated loamy soils and nitrates can be leached and pollute the groundwater 548 (Darwish et al., 2003). 
549 Regarding the net profit (Fig. 4c), it is obvious from the results that the wheat-potato 550 rotation is the most profitable rotation among the different rotations (from 8500 551 US\$/rotation/ha to 8700 US\$ rotation $^{-1}$ per ha). Wheat-fava bean (around 2000 US\$ 552 rotation $^{-1}$ per ha) and wheat-wheat (around 1300 US\$ rotation ${ }^{-1}$ per ha) rotations follow.

553 Eventually, wheat-fallow is the least profitable in terms of net profit (around 660 US\$ 554 rotation $^{-1}$ per ha). This also confirms, therefore, that the cropping systems within the area 555 are over-fertilized since efficiency decreases while the net profit does not witness a similar 556 increase when intensifying the management system. In the long term, these practices may 557 affect soil-ecosystem functions.

558 The wheat-potato rotation is the riskiest one, compared to other rotations. In addition, the 559 wheat-fava bean rotation is not just more profitable than the wheat-wheat rotation, it is also 560 economically much less risky. Thus, growing legumes in rotation with wheat reduces 561 economic risk, as well as water and nitrogen dependence, compared to other rotations. 562 Similarly, and on a more general basis, in low WHC soil types, the more intensive the 563 systems, the riskier (economically) they are. This result contradicts several other studies 564 that suggest intensification, as a factor, to increase production stability (Gaudin et al., 2015; 565 Hartmann et al., 2015). This result shows that by intensifying the system in low WHC, that 566 is to say dry-land soils that are poor in terms of physical and biological properties, 567 productivity remains, efficiency decreases and economic and environmental sustainability 568 decrease.

569 By looking at the WUE, intensive systems (except wheat-fallow rotations) are more 570 efficient in terms of water-use than extensive systems. This result is consistent with the 571 literature, which mentions that water is one of the most limiting factors in shallow soils of 
572 arid areas (Sultana et al., 2009). Semi-intensive and extensive systems (systems 8, 9, 11,

$57312,13,15$ and 16) are then less efficient in terms of WUE. Wheat-fallow systems

574 (especially the extensive ones: 10 and 14) are the least efficient in terms of water, basically

575 due to large amounts of evaporated water.

577 By looking at the NUE (Fig. 5a \& 5c), in high WHC soil, two groups of systems could be 578 observed, belonging to fertilized (low NUE) and unfertilized systems (high NUE). Within 579 the second group, wheat-fava bean (systems 4, 8, 12 and 16) and wheat-fallow (systems 2, 5806,10 and 14) rotations are superior to wheat-wheat (systems 1, 5, 9 and 13) and wheat581 potato (systems 3, 7, 11 and 15) rotations in terms of NUE. With respect to protein 582 production (Fig. 5a), wheat-wheat and wheat-fava bean rotations were the best rotations 583 compared to the other two rotations (1.2 to $1.5 \mathrm{t}^{\text {rotation }}{ }^{-1}$ per ha), followed by wheat584 potato ( $1.1 \mathrm{t}^{\text {rotation }^{-1}}$ per ha) and wheat-fallow ( 0.7 to $0.8 \mathrm{t}^{\text {rotation }}{ }^{-1}$ per ha) rotations. 585 Results for soils with high WHC show that all rotations (except the wheat-wheat rotation) 586 are over-fertilized. As for the net profit, regardless of the soil type and WHC, the wheat-

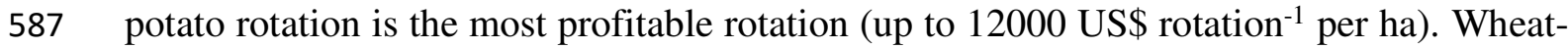
588 fava bean and wheat-wheat rotations follow (3500 US\$/rotation/ha and 2500 589 US\$/rotation/ha, respectively). The wheat-fallow rotation comes last with around 1500 590 US\$/rotation/ha.

591 Comparing the results of high WHC to those of low WHC soil types, wheat-wheat and 592 wheat-potato rotations in high WHC soils become much less risky (if intensive 593 management in terms of nitrogen is avoided) in terms of economic risk of low productivity. 
594 Wheat-fallow and wheat-fava bean rotations, similarly to low WHC soils, are the least 595 risky, economically, if adopted by farmers.

596 Regarding the WUE (Fig. 5b \& 5d), the results show that water is not a limiting factor in 597 high WHC soils (Zhang et al., 2008). Even though fertilized systems have shown slightly 598 higher WUE than non-fertilized systems, the difference is not significant.

\section{4. Discussion}

601 When considering high resource-use efficiency, high system productivity (protein and 602 profit) as well as low economic risk in terms of system sustainability as a whole package, 603 it is clear that there is no comprehensible optimal scenario. Depending on our simulation 604 results, the productivity (protein and net profit) of the different wheat-based cropping 605 systems in two different soil WHC types, taking into consideration risk and wheat 606 efficiency results, are plotted on a conceptual guide-map (Fig. 6). In addition, the

607 productivity frontier is displayed to understand the best attainable scenarios.

608

609 Using this conceptual guide-map (Fig. 6) is essential for comparing the performance of the 610 different wheat-based cropping systems, but also to identify the possible levers to improve 611 the performance of these systems:

612 - Preserving deep soils for wheat cultivation: Such a strategy is achieved by combatting 613 ongoing soil degradation, especially in dry and sub-dry areas. The presence of many typical 614 cereal area plains in the Mediterranean region with low soil water holding capacity results 615 in grain yield reduction due to post-anthesis terminal drought where a strong relationship 
was found between actual evapotranspiration in the grain filling phase and the final grain

617 yield. (Karrou and Oweis, 2012). As an example, the soil in the Medjerda-Tunisia (Souissi

618 et al., 2017), Saïs-Morocco (Mohamed et al., 2018) and the Bekaa plain of Lebanon

619 (Darwish et al., 2006b) typical cereal plains are more than $60 \%$ characterized by a low

620 water holding capacity.

621 Deep soils in arid area are currently mostly dominated by cereal crops (especially durum

622 and soft wheat), but a wide range of irrigated crops can also be observed, such as

623 vegetables, orchards and fodder crops which represent at least $30 \%$ of the total cultivated 624 area (Caiserman et al., 2019). These crops are less sensitive to the depth of the soil than 625 cereal crops. Therefore, keeping deep soils for cereals could be a leverage for policy626 makers in order to increase their production, input-use efficiency, and reduce the economic 627 risk of low relative productivity by at least $48 \%, 35 \%$ and $38 \%$ respectively, as shown in 628 this study.

629 - Reduction of the areas dedicated to wheat-fallow cropping systems (WF in Fig.5): such a 630 cropping system is characterized by low economic and nutritional performances compared 631 to other cropping systems. This explains why this system has gradually disappeared from 632 arid areas, and only exists for those practicing multiple activities (MoA, 2010). For those 633 farmers, the advantage of this system is that it requires very few inputs (particularly in high 634 WHC soils) and especially involves very little risk compared to other cropping systems. 635 Today, in the Mediterranean region, even if the areas dedicated to this type of rotation are 636 less common than those dedicated to other rotation types, half of the land is left 637 uncultivated each year (López-Bellido and López-Bellido, 2003). Most of the current 638 intensification policies in dry areas encourage the mobilization of more inputs by totally or 
639 partially subsidizing access to irrigation water, fertilizers, seeds, etc. By promoting wheat-

640 based alternative systems other than wheat-fallow, it is potentially possible, according to

641 our results, to increase rotational ( 2 year) protein production by at least $50 \%$, at the Bekaa

642 plain level.

643 - Intensification of wheat cultivation by increasing the amount of inputs: as expressed

644 before, this lever is the most used by policy-makers and farmers to increase wheat 645 production (Pala et al., 2007; Sadras, 2004). The guide-map (Fig. 6) shows that the 646 intensification by increasing inputs is not effective in all cropping systems and the effects 647 on rotational performance, efficiency and risk are not consistent with all cropping systems.

648 Unfortunately, most farmers manage wheat cultivation regardless of the rotation type 649 (Armengot et al., 2011), by considering intensified wheat management systems, presented 650 in a wheat-wheat rotation as a reference pathway to increase productivity (Balkovič et al., 651 2014). Such means, which are encouraged by policy-makers, are not always reasonable as 652 the efficiency of wheat in utilizing the resources decreases dramatically in different dry 653 areas in the Mediterranean (Ben Zekri et al., 2018; Giménez et al., 2016; Ryan et al., 2007; 654 Souissi et al., 2017; Yau et al., 2003).

655 - Switching from wheat-wheat rotation to wheat-legume crops (fava bean in our study): 656 The wheat-legume rotation has shown better productivity than the wheat-wheat system, 657 significantly higher efficiency (nitrogen and water) and much lower economic risk. Such 658 findings were not very surprising as diversified rotations with catch crops usually yield 659 high NUE (Beaudoin et al., 2005; Hansen et al., 2015; Moreau et al., 2012). Growing winter 660 wheat with low inputs leads to a small sacrifice in terms of productivity, which may be a 661 reason why farmers prefer intensified wheat-wheat cropping systems. Apart from 
fertilization, mechanization limitations in legumes cultivation and the dependence on

663 labour (weeding, harvesting) and establishments (e.g. storage warehouses), which would

664 be pricey if not already owned by the farmer, are also obstacles preventing farmers from

665 an easy switch to wheat-legume rotations. Moreover, fava beans production is a local

666 product, which is sold locally and thus linked to the national level. This could be attributed

667 to the low-trust that is given by farmers regarding national and local markets fearing

668 "unlawful speculation". Instead, many of them would prefer investing in wheat cultivation

669 knowing in advance that the prices will not witness any change (even if negligible), as the

670 government buys the grain yield.

671 Indeed, wheat farmers in Lebanon as well as in the MENA region do over-fertilize their

672 crops for several reasons. First, farmers tend to believe that applying high rates of $\mathrm{N}$ would

673 decrease their economic risk by increasing the grain weight and the final grain yield, and

674 second because they do benefit from stable prices due to the support system at the national

675 level. This issue (over-fertilization) has been widely reported in Tunisia (Cheikh M'hamed

676 et al., 2014; Thabet et al., 2010), Egypt and Morocco (FAO, 2018). In another study, it was

677 also reported that the over nitrogen fertilization all over the Mediterranean is highly

678 impacting, negatively, the soil and water quality in the area in addition to reducing the

679 economic yield (the huge $\mathrm{N}$ input represents $15 \%$ of the input cost in Morocco) (Heng et

680 al., 2007). On the other hand, a study in Italy has suggested the increase of nitrogen 681 application to up to $200 \mathrm{~kg} \mathrm{ha}^{-1}$ (similar to the rates applied in the Bekaa plain) for higher 682 grain weight and better yield, taking into account the high environmental impacts (e.g. 683 nitrogen leaching) (Abad et al., 2004).

\section{Conclusions}


Broadly, as frequently cited, increased production as well as increasing the efficiency in using the resources are the main requirements for feeding a vastly growing and changing world (Godfray et al., 2010). Many farmers, who work under small profit margins seek high production as a primary goal like many industrialized systems, which definitely trade off against ecosystem values and environmental aspects (Foley et al., 2005). Such an approach eventually leads to what we witness today in terms of negative environmental consequences and resource depletion (Pimentel, 2005), as well as negative social impacts (Marks et al., 2010). The results of our research showed that careful considerations should be coupled with recommending a specific cropping system, especially at field level. No optimal scenario was found (rotation and management) that may simultaneously guarantee low risk, significant protein production, large net profit, and high resource-use efficiency (NUE and WUE), at least for the rotations simulated in this study. Several studies have analyzed one crop (or one cropping system) in relation to its productivity and efficiency. Our results, nevertheless, by allowing the farmers and policy-makers to categorize existing systems in terms of their performance and risk, indicate that at field level, a wheat-legume rotation in which wheat is cultivated under semi-intensive and/or extensive agricultural management is very recommended, especially for those who cannot bear high-risk systems, securing both high efficiency in terms of resource-use and great protein production. In future research, anticipating our results, we intend to upgrade this study to the farm level, where more criteria and parameters may come across to propose a whole integrated system that is profitable, non-risky and sustainable, overpowering food security deterioration and nevertheless efficient in terms of resource-use efficiency. 


\section{Acknowledgments}

709 The authors acknowledge the Conseil National de la Recherche Scientifique (CNRS-

710 Liban) for financially supporting the project, which was implemented in collaboration with

711 the Mediterranean Agronomic Institute of Montpellier, France (CIHEAM-IAM) and 712 IRSTEA (Montpellier, France). They declare no conflict of interest.

\section{References}

714 Abad, A., Lloveras, J., Michelena, A., 2004. Nitrogen fertilization and foliar urea effects

Acutis, M., Scaglia, B., Confalonieri, R., 2012. Perfunctory analysis of variance in

Ahmed, G., Hamrick, D., Gereffi, G., 2014. Shifting Governance Structures in the Wheat Value Chain : Implications for Food Security in the Middle East and North Africa. Centrorossidoria.It 1-28. 

https://doi.org/10.1071/CP14252

Armengot, L., José-María, L., Blanco-Moreno, J.M., Bassa, M., Chamorro, L., Sans, F.X., 2011. A novel index of land use intensity for organic and conventional farming of Mediterranean cereal fields. Agron. Sustain. Dev. 31, 699-707. https://doi.org/10.1007/s13593-011-0042-0

Asseldonk, M. Van, Burger, K., Maitre, E., Muller, B., 2013. Linking crop insurance and rural credit.

Asseng, S., Turner, N.C., Keating, B.A., 2001. Analysis of water- and nitrogen-use efficiency of wheat in a Mediterranean climate. Plant Soil 233, 127-143.

Balkovič, J., van der Velde, M., Skalský, R., Xiong, W., Folberth, C., Khabarov, N., Smirnov, A., Mueller, N.D., Obersteiner, M., 2014. Global wheat production potentials and management flexibility under the representative concentration pathways. Glob. Planet. Change 122, 107-121. https://doi.org/10.1016/j.gloplacha.2014.08.010

Beaudoin, N., Saad, J.K., Van Laethem, C., Machet, J.M., Maucorps, J., Mary, B., 2005. Nitrate leaching in intensive agriculture in Northern France: Effect of farming practices, soils and crop rotations. Agric. Ecosyst. Environ. 111, 292-310. https://doi.org/10.1016/j.agee.2005.06.006

Belhouchette, H., Braudeau, E., Hachicha, M., Donatelli, M., Mohtar, R.H., Wery, J., 2008. Integrating spatial soil organization data with regional agricultural management simulation model: a case study in northern Tunisia. Am. Soc. Agric. 
Biol. Eng. 51, 1099-1109.

Ben Zekri, Y., Barkaoui, K., Marrou, H., Mekki, I., Belhouchette, H., Wery, J., 2018. On farm analysis of the effect of the preceding crop on $\mathrm{N}$ uptake and grain yield of durum wheat ( Triticum durum Desf.) in Mediterranean conditions. Arch. Agron. Soil Sci. 0, 1-16. https://doi.org/10.1080/03650340.2018.1514111

Bennett, D., Reynolds, M., Mullan, D., Izanloo, A., Kuchel, H., Langridge, P., Schnurbusch, T., 2012. Detection of two major grain yield QTL in bread wheat (Triticum aestivum L.) under heat, drought and high yield potential environments. Theor. Appl. Genet. 125, 1473-1485. https://doi.org/10.1007/s00122-012-1927-2

Berntsen, J., Olesen, J.E., Petersen, B.M., Hansen, E.M., 2006. Long-term fate of nitrogen uptake in catch crops. Eur. J. Agron. 25, 383-390. https://doi.org/10.1016/j.eja.2006.07.006

Braudel, F., 1990. La Méditerranée et le monde méditerranéen à l'époque de Philippe le Bel Tome 1.

Brooks, E.S., Pan, W.L., Lamb, B.K., Stöckle, C.O., Maureira, F., Chi, J., O’Keeffe, P.T., Waldo, S., Pressley, S.N., Huggins, D.R., 2017. Carbon and Water Budgets in Multiple Wheat-Based Cropping Systems in the Inland Pacific Northwest US: Comparison of CropSyst Simulations with Eddy Covariance Measurements. Front. Ecol. Evol. 5, 1-18. https://doi.org/10.3389/fevo.2017.00050

Caiserman, A., Dumas, D., Bennafla, K., Faour, G., Amiraslani, F., 2019. Application of Remotely Sensed Imagery and Socioeconomic Surveys to Map Crop Choices in the Bekaa Valley (Lebanon). Agriculture 9, 57. 
774 Catchpole, W.R., Wheeler, C.J., 1992. Estimating plant biomass: A review of techniques. Aust. J. Ecol. 17, 121-131. https://doi.org/10.1111/j.1442-9993.1992.tb00790.x

Cheikh M'hamed, H., Rezig, M., Naceur, M. Ben, 2014. Deficit Irrigation of Durum

Constantin, J., Beaudoin, N., Laurent, F., Cohan, J.P., Duyme, F., Mary, B., 2011.

Constantin, J., Mary, B., Laurent, F., Aubrion, G., Fontaine, A., Kerveillant, P., Beaudoin, N., 2010. Effects of catch crops, no till and reduced nitrogen fertilization on nitrogen leaching and balance in three long-term experiments. Agric. Ecosyst. Environ. 135, 268-278. https://doi.org/10.1016/j.agee.2009.10.005

Dalal, R.C., Strong, W.M., Weston, E.J., Cooper, J.E., Wildermuth, G.B., Lehane, K.J., King, A.J., C. J. Holmes, 2001. Sustaining productivity of a Vertisol at Warra, Queensland, with fertilisers, no-tillage, or legumes. Aust. J. Exp. Agric. 41.

Darwish, T., Atallah, T., Fadel, A., 2018. Challenges of soil carbon sequestration in the NENA region. Soil 4, 225-235. https://doi.org/10.5194/soil-4-225-2018

Darwish, T., Atallah, T., Hajhasan, S., Chranek, A., 2003. Management of nitrogen by fertigation of potato in Lebanon. Nutr. Cycl. Agroecosystems 67, 1-11. 
Darwish, T.M., Atallah, T.W., Hajhasan, S., Haidar, A., 2006a. Nitrogen and water use efficiency of fertigated processing potato. Agric. Water Manag. 85, 95-104. https://doi.org/10.1016/j.agwat.2006.03.012

Darwish, T.M., Khawlie, M., Jomaa, I., Abou Daher, M., Awad, M., Masri, T., Shaban, A., Faour, G., Bou Kheir, R., Abdallah, C., Haddad, T., 2006b. Soil map of Lebanon: 1: 50 000. CNRS-Lebanon, Monogr. Ser. 4, 367.

Di Falco, S., Perrings, C., 2005. Crop biodiversity, risk management and the implications of agricultural assistance. Ecol. Econ. 55, 459-466. https://doi.org/10.1016/j.ecolecon.2004.12.005

El Khansa, M., 2017. Finding pathways for enhancing irrigated farming systems in Lebanon. Université Montpellier.

FAO, 2018. World fertilizer trends and outlook to, World fertilizer trends.

Foley, J.A., DeFries, R., Asner, G.P., Barford, C., Bonan, G., Carpenter, S.R., Chapin, F.S., Coe, M.T., Daily, G.C., Gibbs, H.K., Helkowski, J.H., Holloway, T., Howard, E.A., Kucharik, C.J., Monfreda, C., Patz, J.A., Prentice, I.C., Ramankutty, N., Snyder, P.K., 2005. Global Consequences of Land Use. Science (80-. ). 309, 570574.

Garabet, S., Wood, M., Ryan, J., 1998. Nitrogen and water effects on wheat yield in a Mediterranean-type climate. I. Growth, water-use and nitrogen accumulation. F. Crop. Res. 57, 309-318. https://doi.org/10.1016/S0378-4290(98)00075-6 
Gaudin, A.C.M., Janovicek, K., Deen, B., Hooker, D.C., 2015. Wheat improves nitrogen use efficiency of maize and soybean-based cropping systems. Agric. Ecosyst. Environ. 210, 1-10. https://doi.org/10.1016/j.agee.2015.04.034

Giménez, C., Stöckle, C.O., Suárez-Rey, E.M., Gallardo, M., 2016. Crop yields and N losses tradeoffs in a garlic-wheat rotation in southern Spain. Eur. J. Agron. 73, 160169. https://doi.org/10.1016/j.eja.2015.11.016

Godfray, H.C.J., Beddington, J.R., Crute, I.R., Haddad, L., Lawrence, D., Muir, J.F., Pretty, J., Robinson, S., Thomas, S.M., Toulmin, C., 2010. Food security: The challenge of feeding 9 billion people. Science (80-. ). 327, 812-818. https://doi.org/10.1126/science.1185383

Gu, B., Kang, S., Liang, Y., Cai, H., Hu, X., Zhang, L., 2002. Effects of limited irrigation on yield and water use efficiency of winter wheat in the Loess Plateau of China. Agric. Water Manag. 55, 203-216. https://doi.org/10.1016/s0378-3774(01)00180-9

Hansen, E.M., Munkholm, L.J., Melander, B., Olesen, J.E., 2010. Can non-inversion tillage and straw retainment reduce $\mathrm{N}$ leaching in cereal-based crop rotations? Soil Tillage Res. 109, 1-8. https://doi.org/10.1016/j.still.2010.04.001

Hansen, E.M., Munkholm, L.J., Olesen, J.E., Melander, B., 2015. Nitrate Leaching, Yields and Carbon Sequestration after Noninversion Tillage, Catch Crops, and Straw Retention. J. Environ. Qual. 44, 868. https://doi.org/10.2134/jeq2014.11.0482

Hartmann, T.E., Yue, S., Schulz, R., He, X., Chen, X., Zhang, F., Müller, T., 2015. Yield and $\mathrm{N}$ use efficiency of a maize-wheat cropping system as affected by different fertilizer management strategies in a farmer's field of the North China Plain. F. 
838

Heng, L.K., Asseng, S., Mejahed, K., Rusan, M., 2007. Optimizing wheat productivity in two rain-fed environments of the West Asia-North Africa region using a simulation model. Eur. J. Agron. 26, 121-129. https://doi.org/10.1016/j.eja.2006.09.001

Huang, M., Dang, T., Gallichand, J., Goulet, M., 2003. Effect of increased fertilizer applications to wheat crop on soil-water depletion in the Loess Plateau, China. Agric. Water Manag. 58, 267-278. https://doi.org/10.1016/S0378-3774(02)00086-0

Jamieson, P.D., Porter, J.R., Wilson, D.R., 1991. A test of the computer simulation model ARCWHEAT1 on wheat crops grown in New Zealand. F. Crop. Res. 27, 337-350. https://doi.org/10.1016/0378-4290(91)90040-3

Kang, S.Z., Zhang, L., Liang, Y.L., Hu, X.T., Cai, H.J., Gu, B.J., 2002. Effects of limited irrigation on yield and water use efficiency of winter wheat in the Loess Plateau of China. Agric. Water Manag. 55, 203-216. https://doi.org/10.1016/s03783774(01)00180-9

Karrou, M., Oweis, T., 2012. Water and land productivities of wheat and food legumes with deficit supplemental irrigation in a Mediterranean environment. Agric. Water Manag. 107, 94-103. https://doi.org/10.1016/j.agwat.2012.01.014

Kehoe, D.P., 1988. Economics of agriculture on Roman imperial estates in North Africa. Vandenhoeck Ruprecht, G€ottingen Popul.

Keller, A.A., Keller, J., 1995. Effective Efficiency: A Water Use Efficiency Concept for Allocating Freshwater Resources. 22. Winrock Int. 20. 
Komarek, A.M., Bell, L.W., Whish, J.P.M., Robertson, M.J., Bellotti, W.D., 2015. Whole-farm economic, risk and resource-use trade-offs associated with integrating forages into crop-livestock systems in western China. Agric. Syst. 133, 63-72. https://doi.org/10.1016/j.agsy.2014.10.008

Komarek, A.M., Drogue, S., Chenoune, R., Hawkins, J., Msangi, S., Belhouchette, H., Flichman, G., 2017. Agricultural household effects of fertilizer price changes for smallholder farmers in central Malawi. Agric. Syst. 154, 168-178. https://doi.org/10.1016/j.agsy.2017.03.016

López-Bellido, L., Muñoz-Romero, V., Benítez-Vega, J., Fernández-García, P., Redondo, R., López-Bellido, R.J., 2012. Wheat response to nitrogen splitting applied to a Vertisols in different tillage systems and cropping rotations under typical Mediterranean climatic conditions. Eur. J. Agron. 43, 24-32. https://doi.org/10.1016/j.eja.2012.05.002

López-Bellido, R.J., López-Bellido, L., 2003. Effects of crop rotation and nitrogen fertilization on soil nitrate and wheat yield under rainfed Mediterranean conditions. Agronomie 21, 509-516. https://doi.org/10.1051/agro:2001140

Macdonald, A.J., Poulton, P.R., Howe, M.T., Goulding, K.W.T., Powlson, D.S., 2005. The use of cover crops in cereal-based cropping systems to control nitrate leaching in SE England. Plant Soil 273, 355-373. https://doi.org/10.1007/s11104-005-0193-3

Mahmood, F., Belhouchette, H., Nasim, W., Shahzad, T., Hussain, S., Therond, O., Fahad, S., Refat Sultana, S., Wery, J., 2017. Economic and environmental impacts of introducing grain legumes in farming systems of Midi-Pyrenees region (France): 
881
Marks, A.R., Harley, K., Bradman, A., Kogut, K., Barr, D.B., Johnson, C., Calderon, N., Eskenazi, B., 2010. Organophosphate pesticide exposure and attention in young Mexican-American children: The CHAMACOS study. Environ. Health Perspect. 118, 1768-1774. https://doi.org/10.1289/ehp.1002056

MoA, 2010. Resultats globaux du module de base du recensement de l'agriculture.

Mohamed, B., Mounia, K., Aziz, A., Ahmed, H., Rachid, B., Lotfi, A., 2018. Sewage sludge used as organic manure in Moroccan sunflower culture: Effects on certain soil properties, growth and yield components. Sci. Total Environ. 627, 681-688. https://doi.org/10.1016/j.scitotenv.2018.01.258

Monzon, J.P., Sadras, V.O., Andrade, F.H., 2012. Modelled yield and water use efficiency of maize in response to crop management and Southern Oscillation Index in a soil-climate transect in Argentina. F. Crop. Res. 130, 8-18. https://doi.org/10.1016/j.fcr.2012.02.001

Moreau, P., Ruiz, L., Raimbault, T., Vertès, F., Cordier, M.O., Gascuel-Odoux, C., Masson, V., Salmon-Monviola, J., Durand, P., 2012. Modeling the potential benefits of catch-crop introduction in fodder crop rotations in a Western Europe landscape. Sci. Total Environ. 437, 276-284. https://doi.org/10.1016/j.scitotenv.2012.07.091

Mueller, N.D., Gerber, J.S., Johnston, M., Ray, D.K., Ramankutty, N., Foley, J.A., 2012. Closing yield gaps through nutrient and water management. Nature 490, 254-257. https://doi.org/10.1038/nature11420 
901

902

903

Musick, J.T., Jones, O.R., Stewart, B.A., Dusek, D.A., 1994. Water-yield relationships for irrigated and dryland wheat in the U.S. southern plains. Agron. J. https://doi.org/10.2134/agronj1994.00021962008600060010x

Nasrallah, A., Baghdadi, N., Mhawej, M., Faour, G., Darwish, T., Belhouchette, H., Darwich, S., 2018. A Novel Approach for Mapping Wheat Areas Using High Resolution Sentinel-2 Images. Sensors 18, 2089. https://doi.org/10.3390/s18072089

Pala, M., Ryan, J., Zhang, H., Singh, M., Harris, H.., 2007. Water-use efficiency of wheat-based rotation systems in a Mediterranean environment. Agric. Water Manag. 93, 136-144. https://doi.org/10.1016/j.agwat.2007.07.001

Palosuo, T., Kersebaum, K.C., Angulo, C., Hlavinka, P., Moriondo, M., Olesen, J.E., Patil, R.H., Ruget, F., Rumbaur, C., Takáč, J., Trnka, M., Bindi, M., Çaldaĝ, B., Ewert, F., Ferrise, R., Mirschel, W., Şaylan, L., Šiška, B., Rötter, R., 2011. Simulation of winter wheat yield and its variability in different climates of Europe: A comparison of eight crop growth models. Eur. J. Agron. 35, 103-114. https://doi.org/10.1016/j.eja.2011.05.001

Passioura, J.B., Angus, J.F., 2010. Improving Productivity of Crops in Water-Limited Environments, 1st ed, Advances in Agronomy. Elsevier Inc. https://doi.org/10.1016/S0065-2113(10)06002-5

Pimentel, D., 2005. ENVIRONMENTAL AND ECONOMIC COSTS OF THE APPLICATION OF PESTICIDES PRIMARILY IN THE UNITED STATES. Environ. Dev. Sustain. 7, 229-252. https://doi.org/10.1007/s10668-005-7314-2 Plaza-Bonilla, D., Nolot, J.M., Raffaillac, D., Justes, E., 2017. Innovative cropping 
systems to reduce $\mathrm{N}$ inputs and maintain wheat yields by inserting grain legumes and cover crops in southwestern France. Eur. J. Agron. 82, 331-341. https://doi.org/10.1016/j.eja.2016.05.010

Rahimizadeh, M., Kashani, A., Zare-Feizabadi, A., Koocheki, A., Nassiri-Mahallati, M.,

Reynolds, S.G., 1970. The Gravimetric Method of Soil Moisture Determination. J.

Rodriguez, I.R., Miller, G.L., 2000. Using a Chlorophyll Meter to Determine the Chlorophyll Concentration, Nitrogen Concentration, and Visual Quality of St. Augustinegrass. HortScience 35, 751-754.

Rötter, R.P., Palosuo, T., Kersebaum, K.C., Angulo, C., Bindi, M., Ewert, F., Ferrise, R., Hlavinka, P., Moriondo, M., Nendel, C., Olesen, J.E., Patil, R.H., Ruget, F., Takáč, J., Trnka, M., 2012. Simulation of spring barley yield in different climatic zones of Northern and Central Europe: A comparison of nine crop models. F. Crop. Res. 133, 23-36. https://doi.org/10.1016/j.fcr.2012.03.016

Ryan, J., Pala, M., Masri, S., Singh, M., Harris, H., 2007. Rainfed wheat-based rotations under Mediterranean conditions: Crop sequences, nitrogen fertilization, and stubble grazing in relation to grain and straw quality. Eur. J. Agron. 28, 112-118. 
946

Sadras, V., 2002. Interaction between rainfall and nitrogen fertilisation of wheat in environments prone to terminal drought: Economic and environmental risk analysis. F. Crop. Res. 77, 201-215. https://doi.org/10.1016/S0378-4290(02)00083-7

Sadras, V.O., 2004. Yield and water-use efficiency of water- and nitrogen-stressed wheat crops increase with degree of co-limitation. Eur. J. Agron. 21, 455-464. https://doi.org/10.1016/j.eja.2004.07.007

Sieling, K., Kage, H., 2006. N balance as an indicator of N leaching in an oilseed rape winter wheat - winter barley rotation. Agric. Ecosyst. Environ. 115, 261-269. https://doi.org/10.1016/j.agee.2006.01.011

Sieling, K., Stahl, C., Winkelmann, C., Christen, O., 2005. Growth and yield of winter wheat in the first 3 years of a monoculture under varying $\mathrm{N}$ fertilization in NW Germany. Eur. J. Agron. 22, 71-84. https://doi.org/10.1016/j.eja.2003.12.004

Sinclair, T.R., Rufty, T.W., 2012. Nitrogen and water resources commonly limit crop yield increases, not necessarily plant genetics. Glob. Food Sec. 1, 94-98. https://doi.org/10.1016/j.gfs.2012.07.001

Singh, A.K., Tripathy, R., Chopra, U.K., 2008. Evaluation of CERES-Wheat and CropSyst models for water-nitrogen interactions in wheat crop. Agric. Water Manag. 95, 776-786. https://doi.org/10.1016/j.agwat.2008.02.006

Sohi, S., Lopez-Capel, E., Krull, E., Bol, R., 2009. Biochar's roles in soil and climate change : A review to guide future research. CSIRO L. Water Sci. Rep. 05/09. 
Souissi, I., Boisson, J.M., Mekki, I., Therond, O., Flichman, G., Wery, J., Belhouchette, H., 2017. Impact assessment of climate change on farming systems in the South Mediterranean area: a Tunisian case study. Reg. Environ. Chang. https://doi.org/10.1007/s10113-017-1130-8

Stockle, C.O., Donatelli, M., Nelson, R., 2003. CropSyst, a cropping systems simulation model. Eur. J. Agron. 18, 289-307. https://doi.org/Pii S1161-0301(02)00109-0

Stockle, C.O., Martin, S.A., Campbell, G.S., 1994. CropSyst, a cropping systems simulation model: Water/nitrogen budgets and crop yield. Agric. Syst. 46, 335-359. https://doi.org/10.1016/0308-521X(94)90006-2

Sultana, H., Ali, N., Iqbal, M.M., Khan, A.M., 2009. Vulnerability and adaptability of wheat production in different climatic zones of Pakistan under climate change scenarios. Clim. Change 94, 123-142. https://doi.org/10.1007/s10584-009-9559-5

Thabet, C., Chebil, A., Othmane, A., 2010. Improving nitrogen and water use efficiency for wheat production in Mediterranean countries: Case of Tunisia. New Medit 9, 5458.

USDA, 2018. National Nutrient Database for Standard Reference.

Valle, P.S., Koesling *, M., Lien, G., Arntzen, H., Flaten, O., Ebbesvik, M., 2004. Risk and risk management in organic and conventional cash crop farming in Norway. Food Econ. - Acta Agric. Scand. Sect. C 1, 195-206. https://doi.org/10.1080/16507540410019692

Voisin, A.-S., Guéguen, J., Huyghe, C., Jeuffroy, M.-H., Magrini, M.-B., Meynard, J.-M., 

bioenergy in Europe: a review. Agron. Sustain. Dev. 34, 361-380. https://doi.org/10.1007/s13593-013-0189-y Berkeley Conf. Agric. Dev.

Yau, S.K., Bounejmate, M., Ryan, J., Baalbaki, R., Nassar, A., Maacaroun, R., 2003. Barley-legumes rotations for semi-arid areas of Lebanon. Eur. J. Agron. 19, 599610. https://doi.org/10.1016/S1161-0301(03)00006-6 wheat in the Mediterranean region. Agric. Water Manag. 38, 195-211. https://doi.org/10.1016/S0378-3774(98)00069-9

998 Zhang, X., Chen, S., Sun, H., Pei, D., Wang, Y., 2008. Dry matter, harvest index, grain 999 yield and water use efficiency as affected by water supply in winter wheat. Irrig. Sci.

$1000 \quad 27,1-10$. https://doi.org/10.1007/s00271-008-0131-2 


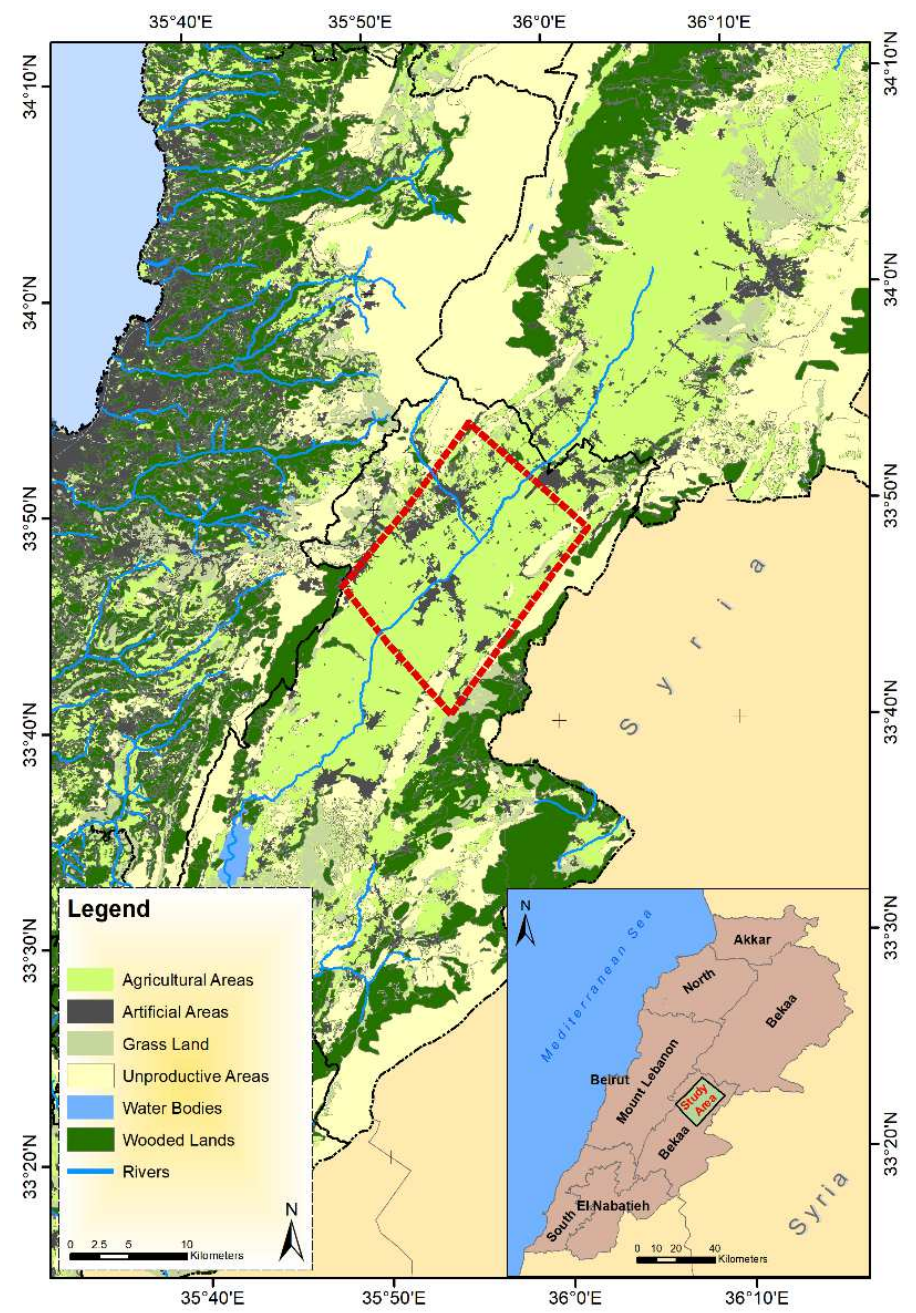

Fig. 1. Location of the Bekaa plain in Lebanon as well as the study area within the red tile
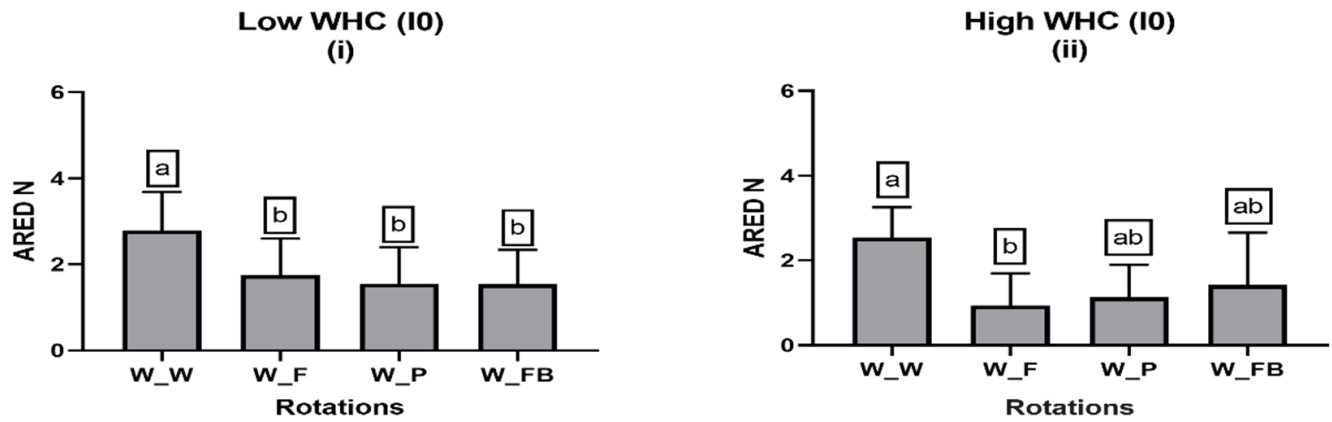


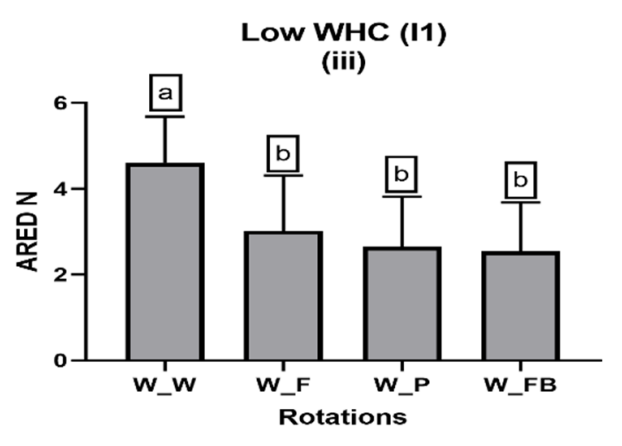

Low WHC (F0)

(v)

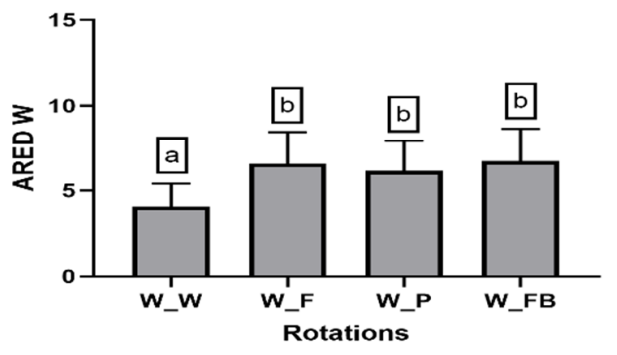

Low WHC (F1)

(vii)

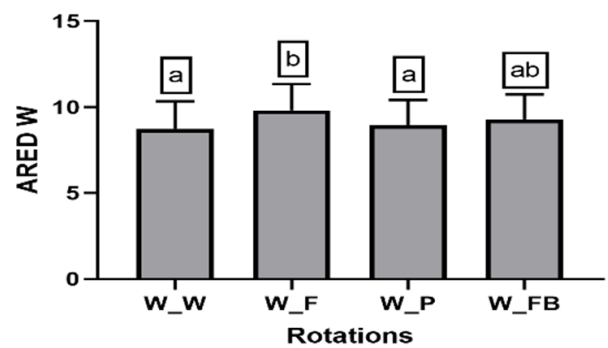

High WHC (I1)

(iv)

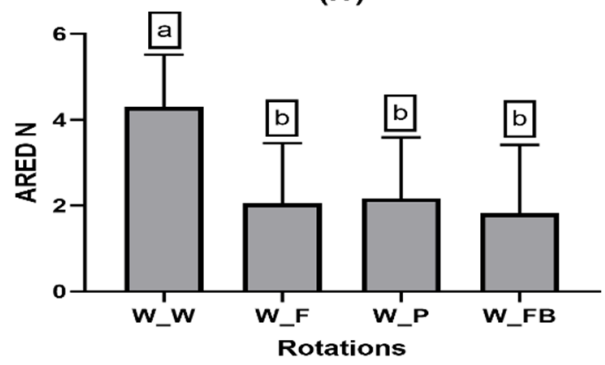

High WHC (FO)

(vi)

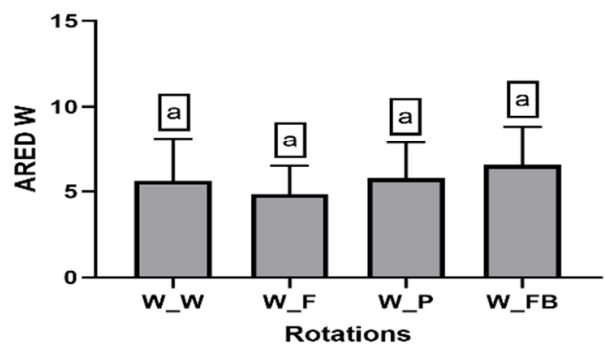

High WHC (F1)

(viii)

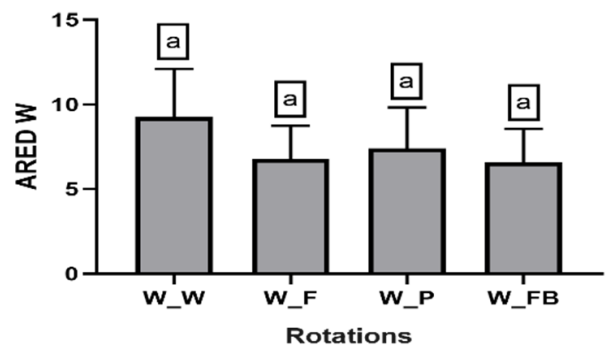

Figure 2. Apparent Recovery Efficiency by Difference (ARED) of nitrogen and irrigation of wheat crops, within each rotation, soil, and management type. a, b and c are symbols characterizing ARED which are significantly different or not regarding rotation.
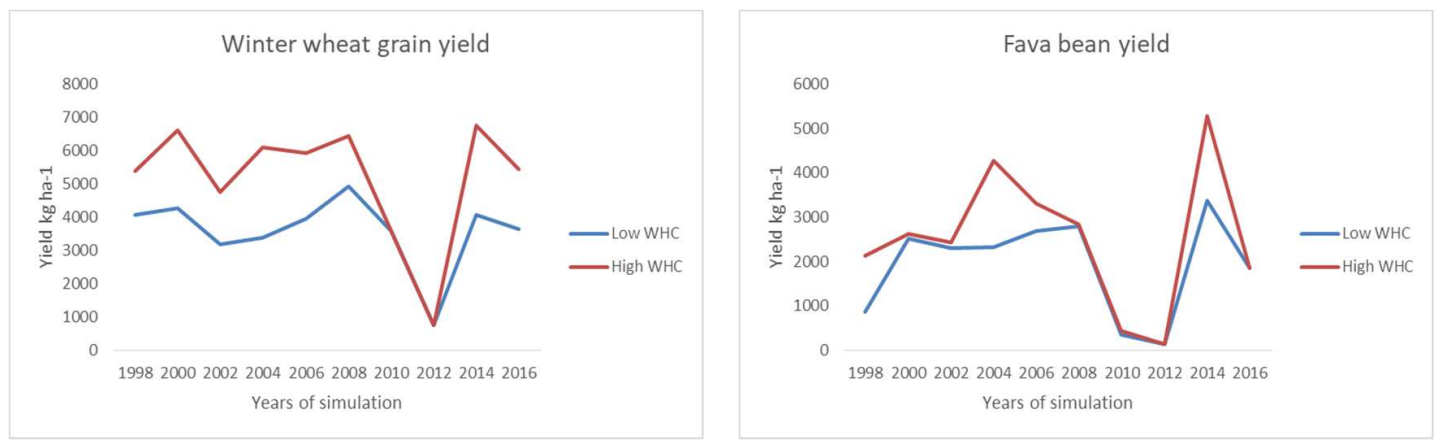


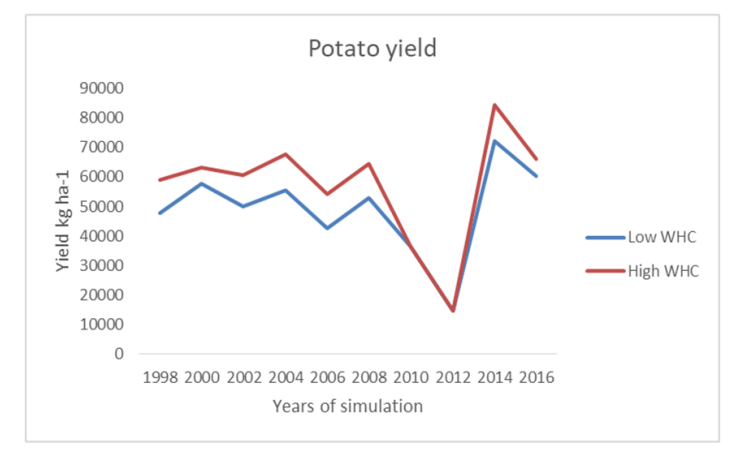

Figure 3. General yield $\left(\mathrm{kg} \mathrm{ha}^{-1}\right)$ trends of the three crops simulated over the 10 rotations in both WHC soils.
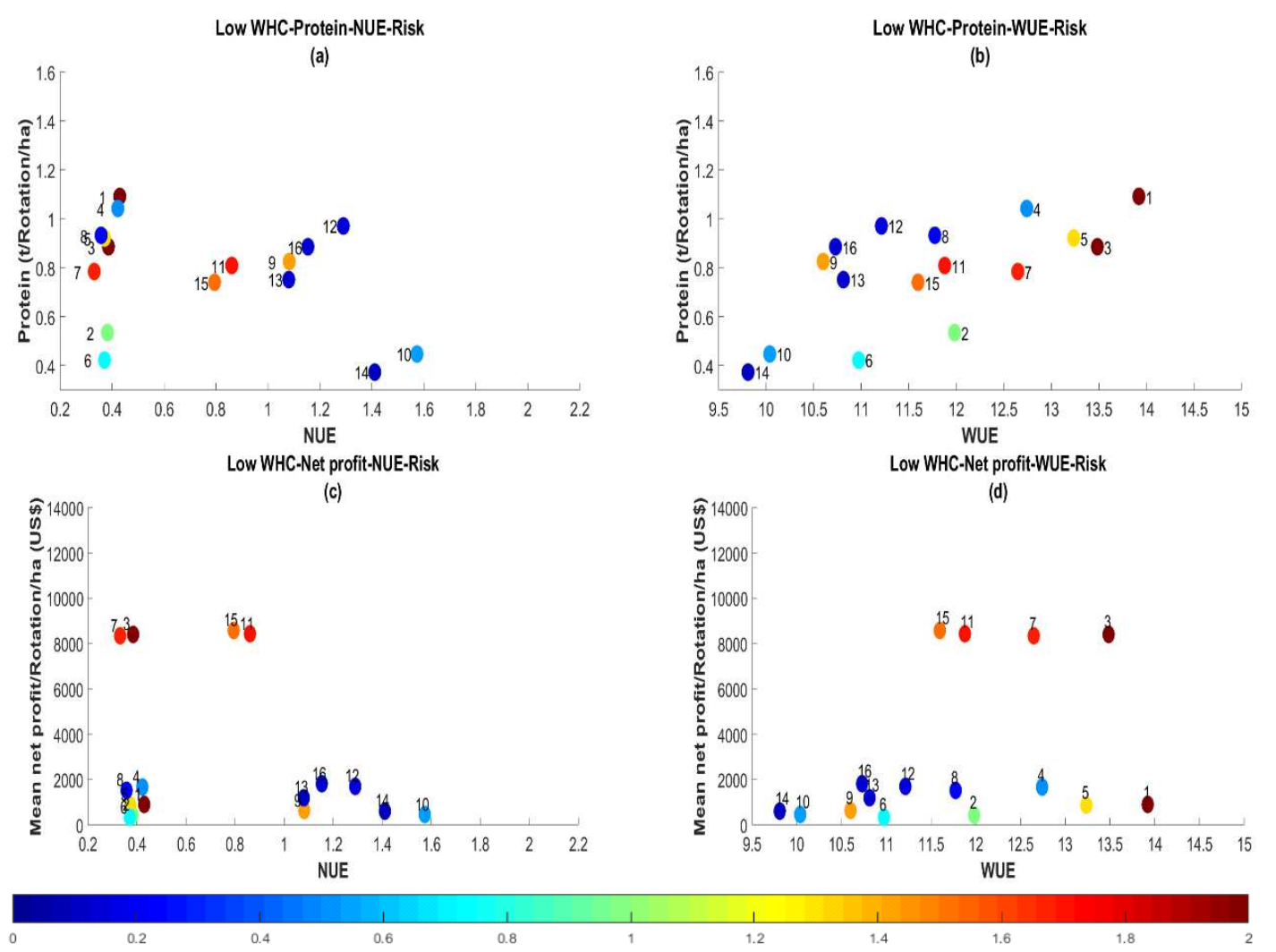

1=WW-F1I1 $2=W F-F 1 I 1$ $3=W P-F 1 \mid 1$ 4=WFB-F1I1 $5=W W-F 110$ $6=W F-F 110$ $7=W P-F 110$ $8=W F B-F 110$ $9=\mathrm{WW}-\mathrm{FOI1}$ 10=WF-FOI 11=WP-FOI 12=WFB-FOI $13=W W-F O I O$ 14=WF-FOIO $15=W P-F 010$ $16=W F B-F O I O$

Figure 4. Risk representation of each of the cropping systems in low WHC soil denoted by the scale bar from dark blue (not risky at all) to dark red (very risky). The variation of protein production at rotational level versus wheat NUE (a) and wheat WUE (b), the variation of net profit at rotational level versus wheat NUE (c) and wheat WUE (d). A legend for each ID is presented to the right of the figure. 

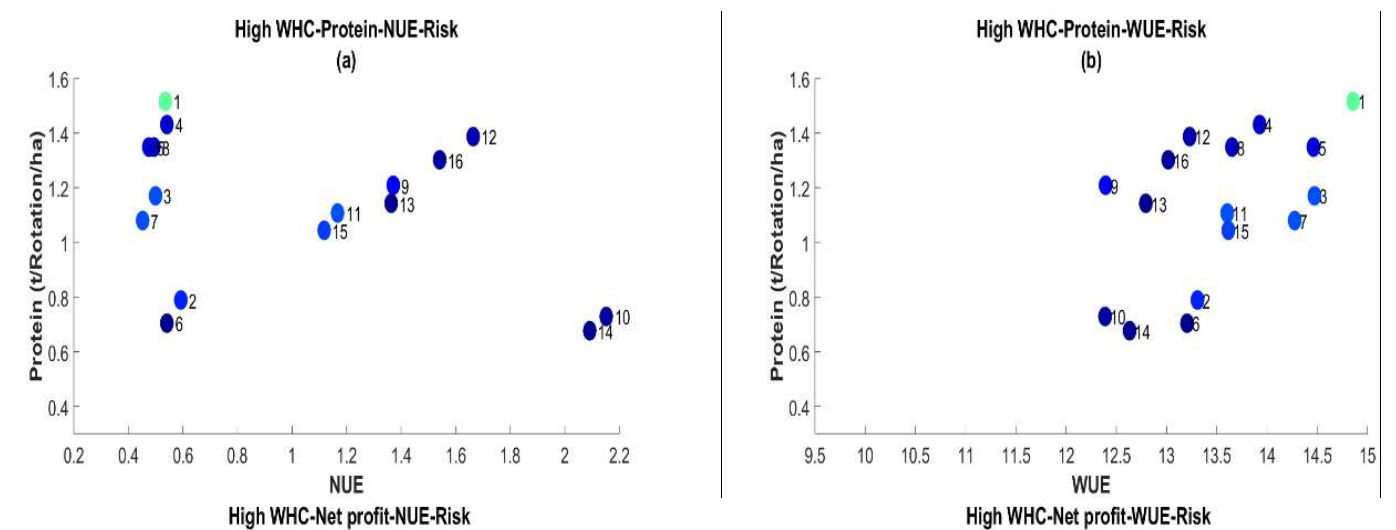

(c)

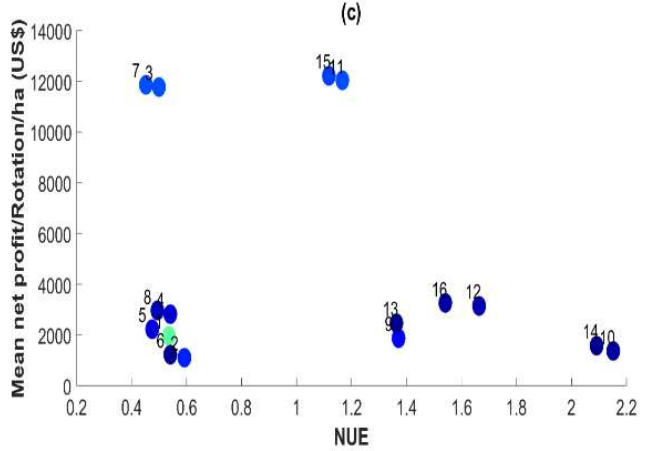

1=WW-F1I1 2=WF-F1I1 $3=\mathrm{WP}-\mathrm{F} 1 \mathrm{I} 1$ 4=WFB-F1I1 $5=W W-F 110$ $6=W F-F 1 I 0$ 7=WP-F1I0 $8=W F B-F 110$ $9=W W-F 0 I 1$ 10=WF-FOI 1 11=WP-FOI1 12=WFB-FOI 1 $13=W W-F O I O$ 14=WF-FOIO 15=WP-FOIO $16=$ WFB-FOIO

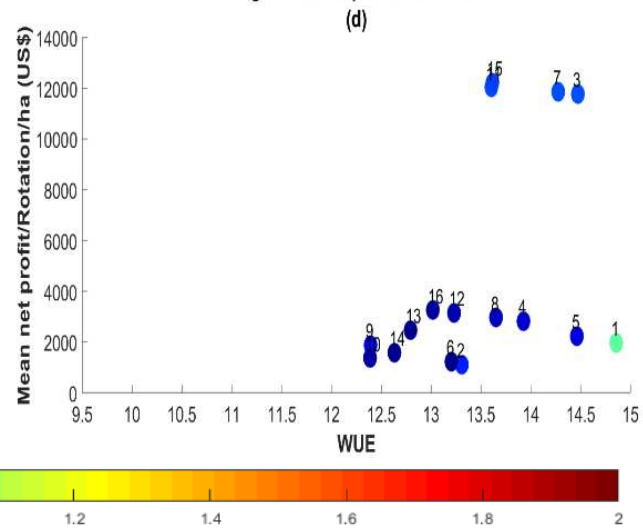

Figure 5. Risk representation of each of the cropping systems in high WHC soil denoted by the scale bar from dark blue (not risky at all) to dark red (very risky). The variation of protein production at rotational level versus wheat NUE (a) and wheat WUE (b), the variation of net profit at rotational level versus wheat NUE (c) and wheat WUE (d). A legend for each ID is presented to the right of the figure. 


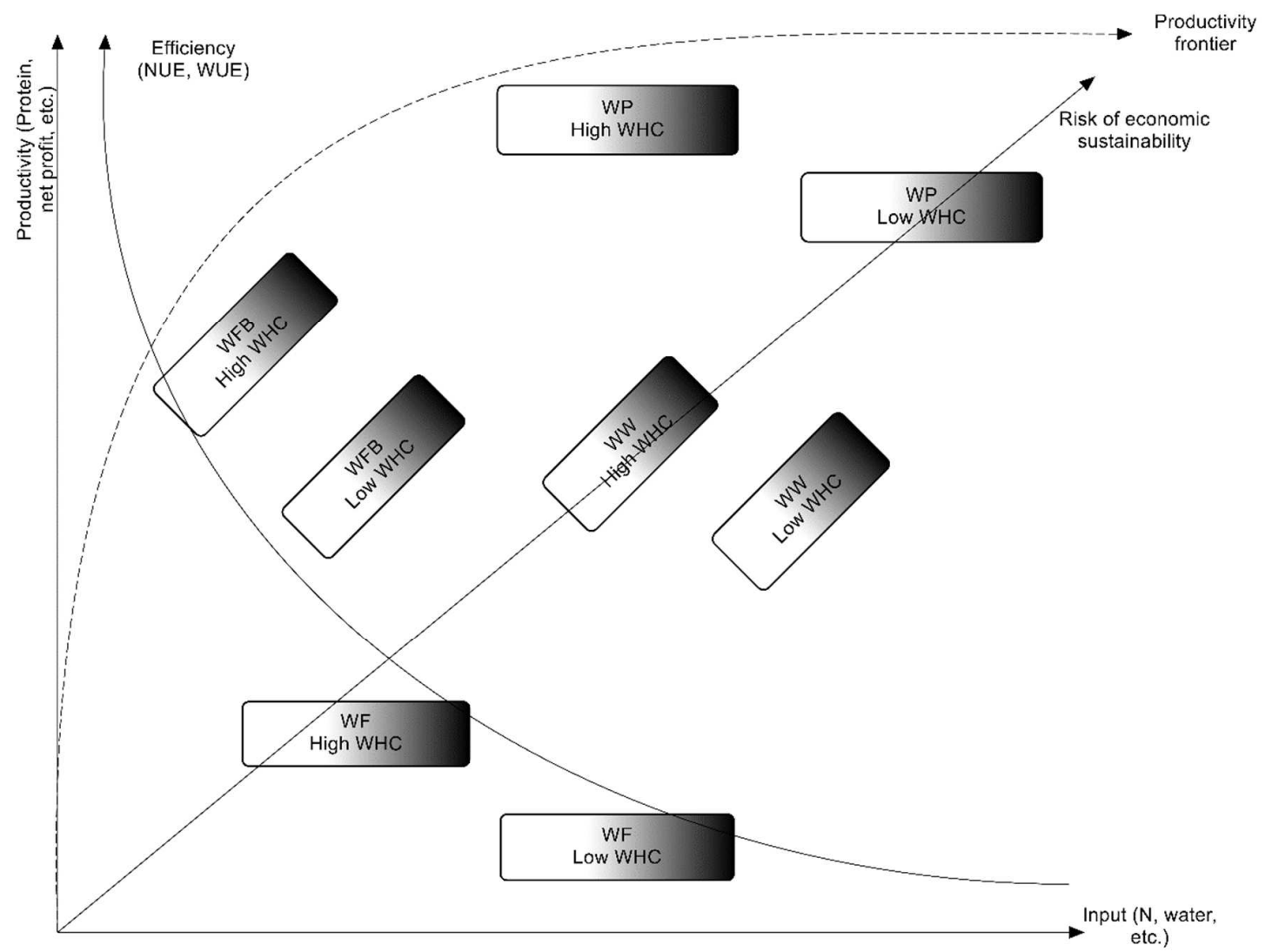

Fig. 6. Conceptual guide-map defining the behavior of the most widespread cropping systems taking into account the inputs of the wheat crop, rotational outputs, wheat efficiency, and economic risk of low relative productivity. WW, WF, WP and WFB correspond to wheat-wheat, wheat-fallow, wheat-potato, and wheat-fava bean rotations, respectively. The darker the represented system area, the more intensive the management system. 
Table 1. Winter wheat reference plot characteristics.

\begin{tabular}{lllllll}
\hline Plot ID & Sowing date & $\begin{array}{l}\text { Harvesting } \\
\text { date }\end{array}$ & $\begin{array}{l}\text { Sowing } \\
\text { density } \\
\left(\text { Seeds } \mathrm{m}^{-}\right.\end{array}$ & $\begin{array}{l}\mathrm{N} \text { applied } \\
\left(\mathrm{kg} \mathrm{ha}^{-1}\right)\end{array}$ & $\begin{array}{l}\text { Irrigation } \\
\text { applied } \\
(\mathrm{mm})\end{array}$ & Soil WHC \\
\hline 1 & $23 / 11 / 2018$ & $02 / 07 / 2018$ & 480 & 230 & 100 & low \\
2 & $20 / 11 / 2018$ & $05 / 07 / 2018$ & 480 & 170 & 240 & high \\
3 & $20 / 11 / 2018$ & $01 / 07 / 2018$ & 480 & 170 & 160 & low \\
4 & $15 / 11 / 2018$ & $01 / 07 / 2018$ & 430 & 280 & 90 & high \\
5 & $23 / 11 / 2018$ & $28 / 07 / 2018$ & 465 & 180 & 0 & high \\
\hline
\end{tabular}

Table 2. Mean and standard deviation results of the in-situ measurements of wheat plots. The measurements correspond to above ground biomass (AGB), above ground nitrogen (AGN), and soil water content (SWC). The measurements took place at 5 physiological stages (1: sowing, 2: tillering, 3: booting, 4: flowering and 5: physiological maturity).

\begin{tabular}{|c|c|c|c|c|c|c|c|}
\hline \multirow[t]{2}{*}{$\begin{array}{l}\text { Plot } \\
\text { ID }\end{array}$} & \multirow[t]{2}{*}{$\begin{array}{l}\text { Physiological } \\
\text { Stage }\end{array}$} & \multicolumn{2}{|c|}{ AGB $\left(\mathrm{kg} \mathrm{ha}^{-1}\right)$} & \multicolumn{2}{|c|}{$\operatorname{AGN}\left(\mathrm{kgN} \mathrm{ha}^{-1}\right)$} & \multicolumn{2}{|c|}{$\begin{array}{c}\mathrm{SWC}\left(\mathrm{m}^{3} \mathrm{~m}^{-}\right. \\
3)\end{array}$} \\
\hline & & Mean & $\mathrm{SD}$ & Mean & SD & $\begin{array}{l}\text { SD } \\
\end{array}$ & Mean \\
\hline 1 & 1 & & & & & 0.05 & 0.39 \\
\hline 1 & 2 & 390 & 138 & 28.2 & 2.8 & 0.02 & 0.39 \\
\hline 1 & 3 & 2527 & 126 & & & 0.02 & 0.4 \\
\hline 1 & 4 & 6410 & 537 & 196.7 & 8.2 & 0.08 & 0.38 \\
\hline 1 & 5 & 9975 & 722 & & & 0.05 & 0.32 \\
\hline 2 & 1 & & & & & 0.03 & 0.26 \\
\hline 2 & 2 & 513 & 30.5 & 26.2 & 1.6 & 0.05 & 0.36 \\
\hline 2 & 3 & 2513 & 533 & & & 0.02 & 0.35 \\
\hline 2 & 4 & 6290 & 377 & 287 & 17 & 0.02 & 0.34 \\
\hline 2 & 5 & 10852 & 577 & & & 0.03 & 0.33 \\
\hline 3 & 1 & & & & & 0.07 & 0.26 \\
\hline 3 & 2 & 600 & 56 & 28.8 & 2.7 & 0.05 & 0.35 \\
\hline 3 & 3 & 2817 & 241 & & & 0.03 & 0.34 \\
\hline 3 & 4 & 5987 & 163 & 250.2 & 6.8 & 0.03 & 0.36 \\
\hline 3 & 5 & 11338 & 463 & & & 0.02 & 0.36 \\
\hline 4 & 1 & & & & & 0.03 & 0.26 \\
\hline 4 & 2 & 529 & 58 & 21.1 & 2.3 & 0.03 & 0.29 \\
\hline 4 & 3 & 2330 & 261 & & & 0.02 & 0.34 \\
\hline 4 & 4 & 5557 & 681 & 222.3 & 27.2 & 0.02 & 0.29 \\
\hline 4 & 5 & 8050 & 349 & & & 0.03 & 0.26 \\
\hline 5 & 1 & & & & & 0.03 & 0.41 \\
\hline 5 & 2 & 660 & 65 & 23.8 & 2.3 & 0.02 & 0.4 \\
\hline 5 & 3 & 2980 & 356 & & & 0.02 & 0.38 \\
\hline 5 & 4 & 5343 & 218 & 224.1 & 9.1 & 0.03 & 0.3 \\
\hline 5 & 5 & 8962 & 730 & & & 0.03 & 0.28 \\
\hline
\end{tabular}

Table 3. Potato and fava bean plot characteristics. The yield is expressed in dry matter (at a standard level of moisture).

\begin{tabular}{llllll}
\hline Crop and ID & Sowing date & Harvesting date & $\begin{array}{l}\mathrm{N} \text { applied } \\
\left(\mathrm{kg} \mathrm{ha}^{-1}\right)\end{array}$ & $\begin{array}{l}\text { Irrigation } \\
\text { applied }(\mathrm{mm})\end{array}$ & $\begin{array}{l}\text { Yield } \\
\left(\mathrm{kg} \mathrm{ha}^{-1}\right)\end{array}$ \\
\hline Potato 1 & $05 / 03 / 2018$ & $10 / 07 / 2018$ & 100 & 560 & 50000 \\
Potato 2 & $05 / 03 / 2018$ & $15 / 07 / 2018$ & 193 & 600 & 37000 \\
Potato 3 & $01 / 03 / 2018$ & $21 / 06 / 2018$ & 370 & 700 & 40000 \\
Potato 4 & $10 / 03 / 2018$ & $17 / 07 / 2018$ & 370 & 500 & 40000 \\
Fava bean 1 & $10 / 11 / 2017$ & $05 / 05 / 2018$ & 50 & 50 & 1201 \\
Fava bean 2 & $08 / 11 / 2017$ & $15 / 05 / 2018$ & 50 & 0 & 945 \\
Fava bean 3 & $12 / 11 / 2017$ & $11 / 05 / 2018$ & 0 & 0 & 1125
\end{tabular}


Table 4 Soil characteristics in where the pilot fields were selected in the mid Bekaa plain of Lebanon.

\begin{tabular}{|c|c|c|c|c|c|c|c|c|}
\hline Low & $\begin{array}{l}\text { Depth } \\
\text { (m) }\end{array}$ & Soil Class & Sand \% & Clay \% & OM\% & $\begin{array}{l}\mathrm{BD} \quad(\mathrm{g} \\
\mathrm{cm}^{-3)}\end{array}$ & $\begin{array}{l}\text { WP } \\
(\% \mathrm{Vol})\end{array}$ & $\begin{array}{l}\mathrm{FC} \\
(\% \mathrm{Vol})\end{array}$ \\
\hline Horizon 1 & 0.1 & Cambisols & 30 & 56 & 2.3 & 1.29 & 33.2 & 44.6 \\
\hline Horizon 2 & 0.25 & Cambisols & 25 & 55 & 2.2 & 1.28 & 32.6 & 44.1 \\
\hline Horizon 3 & 0.3 & Cambisols & 18 & 56 & 1.8 & 1.35 & 32.8 & 44.2 \\
\hline Horizon 4 & 0.4 & Cambisols & 25 & 48 & 1.9 & 1.33 & 33 & 44.4 \\
\hline \multicolumn{9}{|l|}{ High } \\
\hline Horizon 1 & 0.1 & Cambisols & 29 & 55 & 2.6 & 1.3 & 32.6 & 44.1 \\
\hline Horizon 2 & 0.35 & Cambisols & 25 & 55 & 2.8 & 1.32 & 32.5 & 44 \\
\hline Horizon 3 & 0.55 & Cambisols & 16 & 50 & 2.2 & 1.28 & 29.6 & 42.2 \\
\hline Horizon 4 & 0.4 & Cambisols & 25 & 45 & 2 & 1.34 & 27.1 & 40.1 \\
\hline
\end{tabular}

Table 5. Cropping system scenarios simulated using CropSyst. Each cropping system scenario consists of a rotation type and wheat management system. 16 cropping systems were simulated in two soil water holding capacity types, leading to 32 scenarios.

\begin{tabular}{llllll}
\hline \multicolumn{2}{l}{ Low Soil holding capacity (LSC) } & \multicolumn{3}{l}{ High soil holding capacity (HSC) } \\
\hline Scenario & Rotation & Management & Scenario & Rotation & Management \\
\hline 1 & Wheat-Wheat & F1-I1 & 17 & Wheat-Wheat & F1-I1 \\
2 & Wheat-Wheat & F1-I0 & 18 & Wheat-Wheat & F1-I0 \\
3 & Wheat-Wheat & F0-I1 & 19 & Wheat-Wheat & F0-I1 \\
4 & Wheat-Wheat & F0-I0 & 20 & Wheat-Wheat & F0-I0 \\
5 & Wheat-Fallow & F1-I1 & 21 & Wheat-Fallow & F1-I1 \\
6 & Wheat-Fallow & F1-I0 & 22 & Wheat-Fallow & F1-I0 \\
7 & Wheat-Fallow & F0-I1 & 23 & Wheat-Fallow & F0-I1 \\
8 & Wheat-Fallow & F0-I0 & 24 & Wheat-Fallow & F0-I0 \\
9 & Wheat-Potato & F1-I1 & 25 & Wheat-Potato & F1-I1 \\
10 & Wheat-Potato & F1-I0 & 26 & Wheat-Potato & F1-I0 \\
11 & Wheat-Potato & F0-I1 & 27 & Wheat-Potato & F0-I1 \\
12 & Wheat-Potato & F0-I0 & 28 & Wheat-Potato & F0-I0 \\
13 & Wheat-Fava bean & F1-I1 & 29 & Wheat-Fava bean & F1-I1 \\
14 & Wheat-Fava bean & F1-I0 & 30 & Wheat-Fava bean & F1-I0 \\
15 & Wheat-Fava bean & F0-I1 & 31 & Wheat-Fava bean & F0-I1 \\
\hline
\end{tabular}




\begin{tabular}{llllll}
\hline 16 & Wheat-Fava bean & F0-I0 & 32 & Wheat-Fava bean & F0-I0 \\
\hline
\end{tabular}

Table 6. Crop input costs and output prices.

\begin{tabular}{lllllll}
\hline $\begin{array}{l}\text { Input } \\
\text { Wheat }\end{array}$ & Cost $\left(\mathrm{US} \$ \mathrm{ha}^{-1}\right)$ & Output & $\begin{array}{l}\text { Price }(\mathrm{US} \$ \\
\left.\mathrm{Ton}^{-1}\right)\end{array}$ & Crop & $\begin{array}{l}\text { Input cost } \\
\left(\mathrm{US} \$ \mathrm{ha}^{-1}\right)\end{array}$ & $\begin{array}{l}\text { Output price } \\
\left(\mathrm{US} \$ \mathrm{Ton}^{-1}\right)\end{array}$ \\
\hline Fertilizers & $400(\mathrm{SD}=47)$ & $\begin{array}{l}\text { Grain } \\
\text { yield }\end{array}$ & 360 & Potato & $9150(\mathrm{SD}=1556)$ & $330(\mathrm{SD}=43)$ \\
Water & $450(\mathrm{SD}=48)$ & Straw & $50(\mathrm{SD}=8)$ & Fava bean & $745(\mathrm{SD}=78)$ & $\begin{array}{l}1000 \\
(\mathrm{SD}=114)\end{array}$ \\
$\begin{array}{l}\text { Labor+ Pesticides } \\
\text { Seeds }\end{array}$ & $\begin{array}{l}450(\mathrm{SD}=70) \\
200(\mathrm{SD}=31)\end{array}$ & & & & & \\
\hline
\end{tabular}

Table 7. Wheat grain yields in different soil water holding capacities (WHC), rotations and management systems in dry Mediterranean conditions. The statistically different groups are represented by different letters $(a, b$ and $c)$ characterizing yields with significant difference (Tukey test at $<$ alpha $>=0.05$ ).

\begin{tabular}{|c|c|c|c|c|c|}
\hline \multicolumn{6}{|c|}{ Wheat grain yield $\left(\mathrm{kg} \mathrm{ha}^{-1}\right)$} \\
\hline Management & & Type & f rotation & & ANOVA \\
\hline & Wheat-Wheat & Wheat-Fallow & Wheat-Potato & Wheat-Fava bean & (Rotation) \\
\hline \multicolumn{6}{|l|}{ Soil with low WHC } \\
\hline F1-I1 & 4513 & 4374 & 4515 & 4404 & $\mathrm{a}, \mathrm{b}, \mathrm{a}, \mathrm{ab}$ \\
\hline F1-I0 & 3787 & 3517 & 3757 & 3601 & $a, b, a, b$ \\
\hline F0-I1 & 3447 & 3705 & 3962 & 3873 & $a, a b, b, b$ \\
\hline $\begin{array}{l}\text { F0-I0 } \\
\text { Significant difference } \\
\text { (Management) }\end{array}$ & $\begin{array}{c}3124 \\
a, b, b c, c\end{array}$ & $\begin{array}{r}3141 \\
a, b, b, b\end{array}$ & $\begin{array}{c}3433 \\
a, b, a b, b\end{array}$ & $\begin{array}{c}3280 \\
a, b c, a b, c\end{array}$ & $\mathrm{a}, \mathrm{a}, \mathrm{b}, \mathrm{ab}$ \\
\hline \multicolumn{6}{|l|}{ Soil with high WHC } \\
\hline F1-I1 & 6083 & 6246 & 6216 & 6117 & $\mathrm{a}, \mathrm{a}, \mathrm{a}, \mathrm{a}$ \\
\hline F1-I0 & 5250 & 5638 & 5549 & 5525 & $\mathrm{a}, \mathrm{a}, \mathrm{a}, \mathrm{a}$ \\
\hline F0-I1 & 5126 & 5818 & 5763 & 5736 & $\mathrm{a}, \mathrm{b}, \mathrm{b}, \mathrm{b}$ \\
\hline $\begin{array}{l}\text { F0-I0 } \\
\text { Significant difference } \\
\text { (Management) }\end{array}$ & $\begin{array}{r}4665 \\
a, b, b, b \\
\end{array}$ & $\begin{array}{c}5421 \\
\mathrm{a}, \mathrm{ab}, \mathrm{ab}, \mathrm{b}\end{array}$ & $\begin{array}{c}5290 \\
\mathrm{a}, \mathrm{ab}, \mathrm{ab}, \mathrm{b}\end{array}$ & $\begin{array}{c}5200 \\
\mathrm{a}, \mathrm{ab}, \mathrm{ab}, \mathrm{b}\end{array}$ & $a, b, b, b$ \\
\hline
\end{tabular}

